\title{
Exploring Efficiency Differentials between Saudi Higher Education Institutions
}

\author{
Wael I. Mousa
}

Al Yamamah University, Riyadh

Saudi Arabia

wisoliman@gmail.com

$\&$

Yaseen Ghulam

Al Yamamah University, Riyadh

Saudi Arabia

$\underline{\text { Y_ghulam@yu.edu.sa }}$ 


\title{
Exploring Efficiency Differentials between Saudi Higher Education Institutions
}

\begin{abstract}
There have been considerable public debates surrounding the efficiency of Saudi higher education institutions, specifically after Vision 2030. We explore the efficiency of institutions of higher learning in Saudi Arabia. Panel data from 61 higher education institutions is employed for the academic years 2008-14 to estimate efficiency scores. Also, second stage regression analysis was employed to identify the main determinants of efficiency scores. We conclude that despite exponential growth in government funding for the higher education sector, technical efficiencies remained almost stagnant over the study period along with a persistence of inefficiencies. Second stage regression results confirm that institution ownership itself does not have a significant effect on efficiency scores. However, being a university and acquiring more than 20 years of experience have a positive impact on efficiency scores. An increase in both lower secondary completion rates and percentage of female students in secondary general education increases efficiencies while higher employment to population ratio and increasing female academic staff ratio in tertiary education reduces institutional efficiencies.
\end{abstract}

JEL classification: C14; D57; I23; J24

Keywords: Efficiency analyses; Universities; Data envelopment analysis; Higher education; Saudi Arabia 


\section{Introduction}

Education is the pivot around which all economic activities cluster and is one of the pillars of a knowledge based economy. Saudi Arabia has been focusing on education in its policies and general budget, comprising one fifth of its government expenditures. In 2015-2016, the government of Saudi Arabia spent SAR 211.8 billion on education alone. The Kingdom spent $8.8 \%$ and $7.3 \%$ of GDP on education in 2016 and 2014, respectively. Gulf Cooperation Council (GCC) countries have been encouraging foreign universities to set-up their campuses in their respective countries by providing them with several incentives, including tax exemptions and infrastructure. Dubai's 'knowledge city' is a classic example leading to the expansion of the number of foreign universities. Similar incentives have been provided by other countries in the gulf region too and attracted many foreign universities. Despite spending a large sum of money on education, the Saudi Arabian government however did not follow this model to promote competition in the sector. Currently many steps in Saudi Arabia in this regard are however being taken, specifically after the launch of Vision 2030, to attract a bigger share of the private sector in general and foreign higher education institutions (HEIs) in particular within the next decade.

Saudi labour market has also witnessed several reform programmes, e.g., Saudization, and Nitaqat, which aimed to provide preferential treatment in academic and administrative recruitments in higher education (HE) sector to Saudi workers. As a result of the labour market reforms and generous government scholarships for studying abroad, the proportion of Saudis academic and non-academic staff in HE has been rising continuously. However, Suadi workers are known to be relatively less productive in the region and this could have significant implication on the operational efficiencies of the higher educational institutions. Similarly, Saudi government has succeeded in increasing the female labour force participation rate from $13.3 \%$ in 2000 to $15.2 \%$ in 
2016 due to increasing focus under Vision 2030 on women participation in educational attainment and labour market activities. Currently, in HEIs, the share of female academic staff is $39.8 \%$ of all academic staff and $42.3 \%$ in administrative and technical jobs. This ratio is expected to increase further in years to come. But, due to a number of cultural and social issues in Saudi Arabia, e.g., dominant share of nonmarket production activities and transportation issues, females face a number of hurdles and could in fact be less productive and efficient compared to their male counterpart. Hence, increasing share of female in labour market could have impacted operational efficiencies of the HEIs too.

Interestingly, despite all the changes mentioned above as a result of reforms process, as well as the booming enrolments in the HE sector due to generous educational scholarship programmes and huge investment in educational infrastructure by the Saudi government, high quality studies on the efficiency and productivity of the Saudi HE sector are very limited or more appropriately nonexistent. This study aims to fill this gap and tries to answer some interesting and important empirical questions, i.e., is there any variation between HEIs efficiencies in terms of type of institution, ownership and age? Are the efficiency sores in HEIs improving over time as a result of labour market adjustments and huge budgetary support? What are the main determinants of efficiency scores for Saudi HEIs? By utilising advanced non-parametric estimators, we compute technical efficiencies of the Saudi HEIs for the period 2008 to 2014 and try to answer above mentioned questions and provide context in this regard.

We believe that studying of efficiency of Saudi HEIs is not only timely but interesting too. The vast majority of Saudi universities are publicly financed. Tighter budget constraints subsequent to reduction in oil prices makes the evaluation of efficiency more important and relevant. There is an increasing focus in the government ministries as well as among general public to utilise resources 
efficiently. The government focus in the years to come would be on issues of accountability, value for money and cost control. In this context, efficiency analyses can be used as an indirect evaluation of public funding utilisation in the higher educational sector in particular. Second, studying this issue can help to evaluate the performance of HEIs, particularly the private HEIs which are gradually becoming an important stakeholders. The findings of this study could also help institutions to benchmark themselves against better and similar types of institutions. Finally, the study contributes to the existing international literature comprising of mostly developed countries. The case study like this from a resource rich country would advance existing knowledge and improves our understanding of the higher educational sector in particular.

The rest of the paper is structured as follows: section two discusses the Saudi HE sector alongside expected changes due to the adoption of Vision 2030 by the Saudi government. The next section presents a review of literature and highlights our contributions towards existing knowledge. Section four contains the methodological framework to estimate a broader family of nonparametric estimators. Section five presents empirical estimates of the technical efficiencies and finally section six reports broader conclusions of the study.

\section{Saudi HE sector}

The HE system of Saudi Arabia depends on public and private universities, colleges and community colleges. The Ministry of Education in Saudi Arabia publishes Higher Education Statistics each year comprising of very interesting and useful information and statistics. Using various issues of this publication, some interesting information could be extracted and summarized in the following paragraphs. Saudi Arabia has witnessed phenomenal growth in the number of universities in the last decade, with the number doubling between 2005 and 2015. The increase in 
the number of universities has created demand for labour specifically academic staff, which has witnessed significant growth during this time period. Saudi lecturer rank has increased by $131 \%$ from 2008 to 2014. In 1977, King Saud University (KSU), the largest university in Saudi Arabia, had $16.2 \%$ Saudi national faculty members (the highest among Saudi universities). In 2016, the ratio of Saudi national academic staff in all Saudi universities reached 59\%. The increase in Saudi faculty members can be attributed to two reasons: i) increase in demand because of the new regulation of the labour market, and ii) increase in the supply due to returning Saudi PhD holders from abroad.

The participation of females in the Saudi HE labour market has been increasing significantly since 2008. Among Saudi teaching staff, the share of female faculty members increased significantly between 2008 and 2016 (cumulative increase of $194.6 \%$ with annual growth rate of $14.5 \%$ vs. male annual growth rate of $8.7 \%$ and accumulative $95.2 \%$ ). Interestingly, the trend for non-Saudi nationals is similar too. The share of female faculty members increased by $204 \%$ compared to $145 \%$ for males. On average, in 2016 , the female teaching staff ratio was $41 \%$ for total academic staff. International faculty represent 89 nationalities. The ratio of international faculty varies between $9 \%-72 \%$ in HEIs. In terms of country of origin of the international faculty members, $69 \%$ of foreign faculty in Saudi public universities are from Arabic speaking countries and another $22 \%$ from other Asian countries (Western countries are represented by only 9\%).

Historically, Saudi Arabia has a stable demand for HE. Student enrolment increased significantly from 2009 to 2015 . The number of freshman-year students increased by $62.4 \%$ and graduate by $35.4 \%$. In Riyadh only, $28 \%$ of the population have above high school degrees. Similarly, the percentage of the population for the age group 25-39 years who hold a HE degree is $44 \%$. The rising demand for HE has been matched by the entry of a number of new institutions. In fact, the 
number of HEIs has increased more than 3 times over the past 16 years. Currently, there are 29 public and 10 private universities, 18 colleges, 8 vocational institutions and colleges, and 1 military health college.

The number of graduates produced by public/private universities, vocational and military colleges during 2010-2014 has increased significantly with an annual average increase of $12.5 \%, 36.1 \%$, and $4.9 \%$ respectively. Similarly, academic human capital formation in Saudi HEIs had an average annual increase of $10 \%, 18 \%$, and $4 \%$ in public and private universities and other HEIs over the period 2011-2015. The increase in private HEIs is consistent with the increase in the number of graduates in the country. In a similar vein, the administrative staff and technicians had an annual average increase of $14 \%, 16 \%$, and $20 \%$ in public, private, and other educational institutes over the period 2011-2015.

Today, the role of contemporary universities goes beyond teaching. Other important dimensions are publishing research papers alongside creating social awareness, advice to the business sector, and innovations. The total number of publications for HEIs in Saudi Arabia over the period 20082015 is 58,882. However, interestingly, the top 3 ranked universities in publications are KSU, King Abdulaziz University (KAU), and King Fahd University for Petroleum and Minerals (KFUPM), which represent on average $65 \%$ of the total publications for the country's HEIs.

\section{Saudi Vision 2030 and education sector}

Saudi Vision 2030, which was announced at the beginning of the second quarter of 2016 by Crown Prince Mohammad Bin Salman, is a plan to reduce the country's dependency on oil and rely on other alternative sources of revenues by diversifying the economy. According to the vision, the country can live without oil by 2020 even if the price of oil falls below $\$ 30$ by increasing non-oil 
exports by six-fold and increasing its share in GDP to 50\%. The plan aims to transform the Kingdom into the heart of the Islamic and Arab world, be the global investment powerhouse and the global hub connecting Asia, Europe and Africa. The plan promises to create a vibrant society, thriving economy and an ambitious nation (Arabia, 2016).

The vision is based on the belief that education will accelerate the economic growth of Saudi Arabia. It is aiming to increase HEIs outputs, meet the requirements of the labour market, develop public education institutions, advise students about potential job opportunities, and increase the number of Saudi universities in the top 200 universities in the world from 2 to 5. Also, it is expected to be implemented by developing curriculums, improving competencies and building character of students, following up on the progress level in the ratios that measure the education outputs continuously, and issuing a comprehensive database to follow the students from early education to advanced.

HEIs are expected to play direct and indirect roles in achieving the goals of the vision. They play a direct role by providing the market labour with graduates matching the demand for labour; on the other hand, HEIs plays an important indirect role in supporting the business sector through research publications which may increase productivity, competitiveness, unlock promising sectors, including agricultural and fishery activities in particular.

To ensure the success of Vision 2030, a set of executive programmes have been formulated which are at the implementation stages. One such programme is National Transformation Program (NTP). The strategic objectives of NTP include:

1. Provide education services for all student levels;

2. Improve recruitment, training and development of teachers; 
3. Improve the learning environment to stimulate creativity and innovation;

4. Improve curricula and teaching methods;

5. Improve students' values and core skills;

6. Enhance the educational system's capability to address national development requirements and to meet labour market demands;

7. Develop creative financing methods and improve the educational system's financial efficiency;

8. Increase private sector participation in the education sector.

The existing Saudi Arabian General Investment Authority policies do not have objections to foreign investment in education. It has been argued on many occasions that 'education is a fundamental building block of the vision as a whole and its progress is likely to be scrutinized carefully. Following this, in addition to encouragement of the private sector's participation and resulting expected inflow of many private institutions from home and abroad, there are serious talks of implementation of an accountability structure to achieve 'value for money' within the Ministry of Education (MOE) by developing key performance indicators (KPIs) at the Ministry level. This study shall hopefully provide some useful efficiency benchmarks for setting up comprehensive accountability standards and the creation of a sense of 'value for money' for the government as well as other stakeholders.

\section{Literature review}

There are several studies which aimed to measure the efficiency of HEIs. Some of these studies are single country studies. Wolszczak-Derlacz and Parteka (2011) provided a list of some of such studies on individual countries. In Table 1: Selective empirical studies using DEA to evaluate the 
efficiency of Higher Education Institutions, we summarise some of these empirical studies which assessed HEIs' efficiency and productivity in both developing and developed countries. For each study, we discuss the main inputs/outputs and main conclusions of these studies. The selection of these particular studies among many is based on almost same research aims and objectives alongside methodological similarities.

[Table 1 near here]

Interestingly, HEIs in Australia have been investigated many times (Avkiran, 2001; Abbott \& Doucouliagos, The efficiency of Australian universities: a data envelopment analysis, 2003; Carrington, Coelli, \& Rao, 2005; Worthington \& Lee, 2008). In the case of European countries and not surprisingly, a significant number of authors from the UK have analysed the efficiency and productivity of the HE sector (Johnes \& Johnes, 1995; Athanassopoulos \& Shale, 1997; Sarrico \& Dyson, 2000; Izadi, Johnes, Oskrochi, \& Crouchley, 2002; Flegg, Allen, Field, \& Thurlow, 2004; Johnes, 2006; Johnes, 2008). Some other country-specific studies on higher/tertiary education systems' efficiency and productivity in the European context include: Italy (Ferrari \& Laureti, 2005; Agasisti \& DalBianco, Data envelopment analysis to the Italian university system: theoretical issues and political implications, 2006; Bonaccorsi, Daraio, \& Simar, 2006; Tommaso \& Bianco, 2006; Agasisti \& Salerno, Assessing the Cost Efficiency of Italian Universities, 2007; Abramo, D’Angelo, \& Pugini, 2008), Austria (Leitner, Prikoszovits, Schaffhauser-Linzatti, Stowasser, \& Wagner, 2007), Germany (Warning, 2004; Fandel, 2007; Kempkes \& Pohl, 2010), Poland (Wolszczak-Derlacz \& Parteka, 2010), Norway (Førsund \& Kalhagen, 1999), the Netherlands (Cherchye \& Abeele, 2005), and Portugal (Afonso \& Fernandes, 2008). Some of the other studies in this regard include: Canada (McMillan \& Datta, 1998), Taiwan 
(Kao \& Hung, 2008; Kuo, Kuo, \& Ho, 2005), and the USA (Bougnol \& Dulá, 2006; Colbert, Levary, \& Shaner, 2000; Moreno \& Tadepalli, 2002).

In Saudi context, Alabdulmenem (2017) applied DEA to measure the relative efficiency of over 25 public universities. The researcher used two input variables, faculty and administrators, while output variables were number of new entrants, number of enrolees, and number of graduates. The estimates revealed that although most public universities in the country are efficient, some fall behind in performance due to poor utilisation of available resources. The main limitation of this study was its lack of including an important output of universities: research publications alongside utilisation of less advanced methods to derive efficiencies.

Al-Mutairi and Al-Shami (2015) performed descriptive analysis of research publications in 25 public universities in Saudi Arabia for the period 1988 to 2013. A total of 42,936 documents published by 25 Saudi universities during the last 6 years were retrieved. Two groups of universities were identified. The first group consists of 6 universities with 35,058 total papers accounting for $82 \%$ of the total. The second group includes 19 universities with 7,878 total papers published, accounting for almost 18\%. The highest number of publications was 15,044 (35\% of total) produced by KSU (3,009 papers /year). Meanwhile, the research publication trend in Saudi Arabia over the period (1988-2013) was slow and lagging from 1988 until 2008 and had remarkable increases thereafter.

In summary, the review of the literature has confirmed that analysis of technical efficiency is a common phenomenon in HE in both developing and developed countries, and also confirms that efficiency analysis of the HE sector typically involves inputs such as labour and capital. Labour is represented by academics, and general and administrative staff. For outputs, the commonly used 
indicators are number of graduates and scientific publications. Interestingly, for Saudi Arabia in particular and GCC countries in general, we were not able to find a study addressing this issue in a comprehensive way nor that was robust in terms of chosen methodology. The only study we report in this review is merely based on the number of publications. Hence, our study fills this important gap and provides a benchmark for HE providers (current and potential) as well as policy planners and government ministries.

\section{Estimation of efficiency}

Significant effort has been made on the methodological front to develop a robust and widely accepted efficiency estimator but consensus has still not been achieved among theorists and practitioners. Two widely used estimators such as stochastic frontier and DEA are subject to a number of issues (Ghulam \& Jaffry, 2015). DEA in particular is going through significant methodological developments to address outlier and statistical inference issues. The estimators developed by Wheelock and Wilson $(2008 ; 2009)$ based on an unconditional $\alpha$-quantile hyperbolic is considered robust, better addresses outlier observations, and is suitable when using few observations and thus avoids the curse of dimensions. This study uses this estimator to estimate efficiency of Saudi HEIs. As a comparison, we also use and report efficiency estimates using simple DEA, Free Disposal Hull (FDH) and partial frontier (order-m) in an effort to stress the importance of using a suitable estimator in estimating and explaining the efficiency score for each decision making unit (DMU).

By following the notations, conventions, definitions and procedures of Wheelock and Wilson (2008; 2009), in the following, we explain our preferred hyperbolic order- $\alpha$ quantile estimator to estimate efficiency scores of the individual educational institution. As discussed above, we also 
estimate traditional FDH and DEA estimators alongside more advanced order-m estimator. Further conceptual details of these estimators for interested reader is presented in Appendix A to conserve space and to avoid repetitions. In addition, we refer to Wheelock and Wilson $(2008 ; 2009)$ for a reader interested in detailed methodological development and estimation of these estimators.

For a very simple case, assume an educational institution uses human capital, which in the efficiency literature is termed input quantities (p) that include academic and administrative staff who produce two output quantities (q) such as number of graduates and publications. By following the literature on efficiency estimations, one could define the standard production possibility set as $\boldsymbol{p}^{t} \equiv\{(x, y) \mid x$ which can produce $y$ at time $\mathrm{t}\} \subset \mathbb{R}_{+}^{p+q}$. The input and output vectors could be represented by p input quantities as $x \in \mathbb{R}_{+}^{p} \mathbf{x} \in \mathrm{R}_{+}^{\mathrm{p}}$ and q output quantities as $y \in \mathbb{R}_{+}^{q}$ representing a feasible combination of input and output at a particular time period. In a broader context, $\boldsymbol{p}^{t \partial}$ in this case represents an upper boundary or benchmark of production frontier $\boldsymbol{p}^{t}$. It is customary to estimate distance from an arbitrary point $(x, y) \in \mathbb{R}_{+}^{p+q}$ to the boundary $\boldsymbol{p}^{t \partial}$ along an assumed direction such as input minimisation or output maximisation.

Wheelock and Wilson (2008) developed a statistical model for a quantile estimator to estimate production boundaries and subsequent distance to these boundaries. In developing the model, the authors introduced some statistical assumptions such as production setP $\boldsymbol{p}^{t}$ is compact and free disposal, sample observations $\mathcal{S}_{n t}^{t}=\left\{\left(x_{\mathrm{i}}, y_{\mathrm{i}}\right)\right\}_{\mathrm{i}=1}^{\mathrm{n}}$ being realization of identically independently distributed (iid) random variables with probability density function $f(x, y)$ with support vector $\mathrm{P}^{t}$. In this context, any point $(x, y)$ is said to be on the frontier ofP, let us say $\boldsymbol{p}^{t \partial}$, if $\left\{\left(\gamma^{-1} x, \gamma y\right)\right\} \notin$ $\boldsymbol{p}^{t}$ for any $\gamma>1$. Furthermore, at the frontier, the density $f_{\mathrm{t}}$ is strictly positive and sequentially lipschitz continuous. 
Under this framework, the authors defined the above density function $f^{t}(x, y)$ as a probability function such as the following:

$$
H^{t}\left(x_{0}, y_{0}\right)=\operatorname{pr}\left(x \leq x_{0}, y \geq y_{0} \text { at time } t\right)
$$

The above function (1) gives the probability of drawing an observation from $f(x, y)$ that weakly dominates DMU operating at $\left(x_{0}, y_{0}\right)$. The dominance idea is based on the fact that institutions are compared in term of their identity and similarity in the use of input mix in the production of output. In this context, hyperbolic approach is based on the idea of dominance.

By rigidly following Wheelock and Wilson (2008) and $\mathrm{u}\left(\mathrm{x}_{0}, \mathrm{y}_{0}\right) \operatorname{sing} H(.,$.$) , the hyperbolic$ distance function is written as:

$$
\gamma^{t}\left(x, y \mid \boldsymbol{p}^{t}\right)=\sup \left\{\gamma>0 \mid H\left(\gamma^{-1} x, \gamma y\right)>0\right\}
$$

while the hyperbolic $\alpha$-quantile distance function is defined as:

$$
\gamma_{\alpha}^{t}(x, y)=\sup \left\{\gamma>0 \mid H^{t}\left(\gamma^{-1} x, \gamma y\right)>(1-\alpha)\right\}
$$

and the hyperbolic $\alpha$-quantile frontier is further defined as:

$$
\boldsymbol{p}_{\alpha}^{t \partial}=\left\{\gamma_{\alpha}^{t}(x, y)^{-1} x, \gamma_{\alpha}^{t}(x, y) y \mid(x, y) \in \boldsymbol{p}^{t}\right\}
$$

The empirical analogue of the above equation (1) for the estimation of $\gamma_{\alpha}^{t}(x, y)$ and corresponding

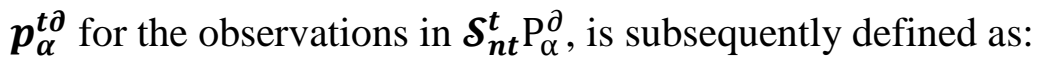

$$
\widehat{\mathrm{H}}_{n}\left(x_{0}, y_{0} \mid \mathcal{S}_{\mathrm{nt}}^{\mathrm{t}}\right)=n_{t}^{-1} \sum_{i=1}^{n} \mathrm{I}\left(x_{i} \leq x_{0}, y_{i} \geq y_{0} \mid\left(x_{i}, y_{i}\right) \in \mathcal{S}_{\mathrm{nt}}^{\mathrm{t}}\right)
$$


Now $\widehat{H}_{\mathrm{n}}\left(\mathrm{x}_{0}, \mathrm{y}_{0}\right)=\mathrm{n}^{-1} \sum_{\mathrm{i}=1}^{\mathrm{n}} \mathrm{I}\left(\mathrm{x}_{\mathrm{i}} \leq \mathrm{x}_{0}, \mathrm{y}_{\mathrm{i}} \geq \mathrm{y}_{0}\right)$ with $\mathrm{I}(\cdot)$ as an indicator function, the estimator of $\boldsymbol{\gamma}_{\boldsymbol{\alpha}}^{\boldsymbol{t}}(\boldsymbol{x}, \boldsymbol{y})$ is developed by replacing $\mathrm{H}(\cdot, \cdot)$ with $\widehat{\mathbf{H}}\left(\cdot, \cdot \mid \boldsymbol{S}_{\mathrm{nt}}^{\mathbf{t}}\right)$ to get the following:

$$
\hat{\gamma}_{\alpha, n t}^{t}(x, y)=\sup \left\{\gamma>0 \mid \widehat{\mathrm{H}}_{n}\left(\gamma^{-1} x, \gamma y \mid \mathcal{S}_{\mathrm{nt}}^{\mathrm{t}}\right)>(1-\alpha)\right\}
$$

Based on the above, computation of $\hat{\gamma}_{\alpha, n t}^{\mathrm{t}}(\mathrm{x}, \mathrm{y})$ turns into a univariate issue and an exact solution is achieved to derive the estimator of the conditional $\alpha$-quantile distance function. Based on a point $\left(\mathrm{x}_{0}, \mathrm{y}_{0}\right)$, the initial values $\gamma_{a}, \gamma_{b}$ are found that bracket the solution in the sense that $\left(\widehat{\mathrm{H}}_{\mathrm{n}}\left(\gamma_{\mathrm{a}}^{-1} x_{0}, \gamma_{\mathrm{a}} \mathrm{y}_{0} \mid \mathcal{S}_{\mathrm{nt}}^{\mathrm{t}}\right)<(1-\alpha)\right.$ and $\left(\widehat{\mathrm{H}}_{\mathrm{n}}\left(\gamma_{\mathrm{b}}^{-1} x_{0}, \gamma_{\mathrm{b}} \mathrm{y}_{0} \mid \mathcal{S}_{\mathrm{nt}}^{\mathrm{t}}\right)<(1-\alpha)\right.$. Some additional steps involve solving for $\hat{\gamma}_{\alpha, n}\left(x_{0}, y_{0}\right)$ by utilising the bisection method. At the estimation stage however, choosing $\alpha$ is a very important factor to be considered by the researcher. We tried different values for $\alpha$ but report efficiency estimates for $\alpha=0.85$ to conserve space.

\section{Choice of inputs and outputs and sources of data}

Kantabutra and Tang (2010) in discussing output in HEIs summarised that some studies considered the combination of teaching and research outputs as educational outcomes (Abbott \& Doucouliagos, The efficiency of Australian universities: a data envelopment analysis, 2003; Avkiran, 2001; Carrington, Coelli, \& Rao, 2005; Fandel, 2007; Førsund \& Kalhagen, 1999; Glass, McCallion, McKillop, Rasaratnam, \& Stringer, 2006; Johnes, Data envelopment analysis and its application to the measurement of efficiency in higher education, 2006; Johnes, Efficiency and Productivity Change in the English Higher Education Sector from 1996/07 to 2002/03, 2008; Kuo, Kuo, \& Ho, 2005; Moreno \& Tadepalli, 2002). Some studies considered only research output (Bougnol \& Dulá, 2006; Cherchye \& Abeele, 2005; Johnes \& Johnes, Research Funding and Performance in U.K. University Departments of Economics: A Frontier Analysis, 1995; Korhonen, Tainio, \& Wallenius, 2001) or teaching output (Abbott \& Doucouliagos, Total Factor Productivity 
and Efficiency in Australian Colleges of Advanced Education, 2001; Colbert, Levary, \& Shaner, 2000). Following several studies mentioned above and because of the lack of financial resources data for Saudi universities, we employed two inputs and two outputs. Inputs are academic and administrative staff. Outputs are number of graduates and publications. Data for academic and administrative staff, and graduates were gathered from the MOE website, while the data for publications were gathered online from Scopus database.

In 2014, KAU (public) had the highest number of academic staff, while the lowest was Riyadh College for Health Sciences (private). The average academic staff for the entire period in the private institutes was less than half of the public institutes. Regarding age, the average age of new institutions was less than one-third of the old institutions (The institution is old if it was established 20 years ago); see Table 2. KSU had the highest administrative staff in 2014, while the lowest was Fakeeh College for Medical Sciences. The average of administrative staff was 855.18. The overall average in private institutions was $67 \%$ of the public institutions for the study period. This overall average in new institutions was $23 \%$ of the average of old institutions.

[Table 2 near here]

KAU also had the highest number of graduate students in 2014 while the lowest was Al-Maarefa College for Science and Technology (private). The average percentage of graduates in public institutions over the study period is $80 \%$ of the total graduates in Saudi Arabia. Finally, KAU had the highest number of publications while the lowest was in private institutions as Inaya Medical College, Mohammad Al-mana College for Health Sciences, and Al-Riyada College for Health Sciences who have zero publications. 
Graduates per academic staff reached its peak for public HEIs in 2011, for private in 2012, for new institutions in 2013, and for old institutions in 2014. For the publications per academic staff, it improved over time in public HEIs, while no large difference was observed in private HEIs. This ratio showed improvement in old institutions in comparison with new institutions. Finally, graduates per administrative staff in public HEIs decreased over the study period, while it was fluctuating in other types of HEIs reaching its peak in private in 2012, new and old in 2014.

Increasing the ratio of graduates to academic staff indicates that the faculty member is spending more time on teaching activities and vice versa. Also, the increase in publications per academic staff is an indication that the faculty are spending more time on research activities, and vice versa. In Saudi Arabia, we can say that in public HEIs they are concerned more with research in comparison with private HEIs. Similarly, for new HEIs, they are keen on teaching rather than research activities compared to old institutions.

\section{Empirical efficiency estimates}

We used the freely available statistical programme "FEAR" written by Wilson (2008) to estimate efficiency. In presenting our empirical findings, we first discuss technical efficiency estimates derived from traditional non-parametric estimators such as FDH and DEA and subsequently from relatively recent estimators such as order-m and $\alpha$-quantile (conditional and unconditional). We estimated efficiency scores based on both input and output orientations as well as hyperbolic graph (in case of DEA) for each year of the sample period for all HEIs using each year production frontier. Figure 1 shows the distribution of efficiency estimates using an unconditional alphaquantile hyperbolic graph estimator. It is clear from the distribution of efficiency estimates that the 
tail appeared to be right skewed indicating that there are a number of educational institutions not using their resources efficiently. We explore this further below.

[Figure 1 near here]

\section{Overall efficiency of HEIs during 2008 - 2014}

We present and discuss the overall sector as well as over different time periods. We use geometric mean in our calculation of efficiency scores over different time intervals. Table 3 contains these efficiency estimates. The FDH estimates of both input and output orientation efficiency scores show inefficiency in the range of $14-16 \%$ over the sample period with some variation over different time periods. As discussed in the empirical literature, relatively high efficiency scores using this estimator could be misleading, indicating perhaps a large number of sample institutions lie close to the efficient frontier due to a high dimension of inputs/outputs space (four in total in our case). Nonetheless, the estimates do not indicate any significant improvement in efficiency over the sample period and in fact show a stagnation (any improvement was eventually offset by a decline over the sample period). The estimates derived from the DEA estimator show roughly the same trend (no significant improvement/decline in efficiency) but the magnitude of inefficiency is higher based on both input and output orientations as well as hyperbolic graph.

[Table 3 near here]

The next set of efficiency estimates used partial frontier (order-m) for input and output orientation. In terms of interpretation of these estimates, the value of input distance function estimate exceeding ' 1 ' suggests the institutions used more than the expected minimum and vice versa. Looking at Table 3, technical efficiency did not change that much over the sample period, in particular 2009 to 2014. On the other hand, in the case of output oriented order-m efficiency 
estimates, an efficiency score exceeding ' 1 ' would reveal that the institution produced more than the expected maximum amount from its observed inputs and vice versa. Again, excluding the first year of the sample period, variation was small and perhaps an indication of a small decline in efficiency based on the last year of the sample period.

As discussed before, the credibility of efficiency estimates derived from estimators such as DEA and FDH is likely to be subject to criticism due to the small sample size (approximately 61-64 educational institutions for each sample period) and slow convergence rates. In our subsequent exercise, we used a conditional and unconditional $\alpha$-quantile estimator to obtain estimates, with root-n convergence rate as well as without imposing a convexity assumption like DEA estimator. Similar to other estimators, broader conclusions remain unchanged. Except for minor adjustments, technical efficiency either remained unchanged or educational institutions witnessed a minor decline irrespective of orientations. Our preferred hyperbolic estimator reveals a more interesting story though. We estimate that, on average, institutions used just $33 \%$ of the input quantity and produced 3 times the output (1/0.3303) than an institution (perhaps hypothetical) located on $\alpha=0.85$ quantile frontier along a hyperbolic path.

\section{Understanding heterogeneity in efficiency amongst different HEIs}

In the subsequent analysis, to find any significant heterogeneity in performance over the sample period, we divided the Saudi HEIs by status (college or university), ownership (publicly owned or privately owned), type of education these institutions provide (general, medical or vocational) and age of institution (older with age $>20$ years and newer with age $<20$ years). Table 4 contains the trend of unconditional hyperbolic $\alpha$-quantile efficiency estimates by status of the institutions. On average, universities appear to be more technically efficiency during our sample period. 
[Table 4 near here]

Although there appears to be significant variation in efficiency levels of two types of institutions (colleges and universities) but interestingly, from 2012 onward, a convergence in these estimates is evident. In fact, the difference between these two types of higher education provider is the lowest in the final year of the sample period. On average, any improvement in efficiency by colleagues was offset by a decline in efficiency for universities during the sample period generally and 2012 in particular.

Table 4 contains the technical efficiency estimates of institutions stratified by ownership. The trend indicates that since 2011 onward, private institutions appear to be relatively less efficient. There is some evidence of convergence in the last two years of the sample period. Ignoring some percentage differences though, public sector institutions with significant backing from the government do not appear to be doing exceptionally well compared to their privately-owned counterparts. In fact, for the period 2008 to 2011 , there was hardly any difference in performance between these two ownership types. On the other hand, if there was any feeling that publicly owned institutions are inherently less efficient compared to small but smart privately-owned institutions, our estimates did not confirm this either. In fact, it was the contrary (although a marginal difference).

The efficiency estimates in Table 4 also reveal the trend in efficiency of the Saudi HEIs stratified by types of education these institutions offer. It appears that vocational institutions started out on the low end, but then caught up in the subsequent years of the sample period. In the last three years of the sample period, these institutions were marginally better compared to those institutions providing either general education or medical/health related education. Medical institutions in general appear to be relatively less efficient but the evidence of catching up in the last three years 
of the sample period is present. In fact in the last year of the sample period, differences between general and medical education providers were minimal.

Lastly, the efficiency estimates in Table 4 reveal the trend in efficiency of the Saudi HEIs stratified by age of the institution. Contrary to the above analysis, there is clear evidence of at least more than $15 \%$ difference between these two types of institutions. Interestingly, this difference widened with the passage of time. It was hardly noticeable during 2008 and 2009. It appears old institutions irrespective of ownership or type of education have utilised their resources comparatively better due to experience and financial muscle and more importantly coped well with competition due to entry of new institutions, in particular private, since 2000 onward.

\section{Analysing of graduates and publications efficiency separately for individual institutions}

Some of the institutions could focus more on one particular output such as number of publications by older established and resource rich publically owned institutions. Private institutions and colleges on the other hand could utilise their resources to produces maximum number of graduates. In an effort to observe this focus and resultant outcome, we re-estimate efficiency scores by considering one output at a time while keeping the same two inputs as before. The outcome of this exercise is presented in table 5. If we view the world rankings, KSU and KAU are in the top 200 in 2014, while King Abdullah for science and technology and KFPM ranked in the top 500 in 2014. Hence, it was not a surprise to find that KSU had the highest production efficiency of publication and overall ranked top. The aggregate and publication efficiencies ranks for the top 4 HEIs were found to be similar. On the other hand, for graduate production efficiency ranking, interestingly and surprisingly, Fakeeh College for Medical Sciences is on top (Table 5).

[Table 5 near here] 
Not surprisingly, due to their more focus on teaching rather than research activities, the top 10 institutions in terms of graduates production efficiency are privately owned new institutions except Technical and Vocational Training Corporations (TVTC), which is a government entity but not a pure academic institution and not relating to MOE. As discussed above, this is not a surprise, because most private and new institutions are at the early stage of their development and called as a teaching institution and perhaps would start focusing on research activity later. The aggregate production efficiency model that is comprises of both outputs is a comprehensive model because it considers both teaching and research activities.

Next, continuing with above separate and aggregate outputs models of efficiencies, we stratified sample institutions by their age. As discussed above, institutions with the age, 20 years and above, are categorised as old and vice versa. The outcome of this exercise is presented in Table 6. Between older institutions, we found KSU and KAU are in the top 2 of 13 institutions in aggregate and publication production efficiency models. In graduate production model, TVTC was on the top followed by KAU. KFUPM was third in aggregate and publication production efficiency models, but was surprisingly last in the graduate production model. This perhaps can be attributed to two possible reasons: firstly, not all specialties are offered at this university; secondly, the younger population concentration is not the same across the different regions of Saudi Arabia.

For the newer HEIs, we found Alfaisal University, a private university, at the top for aggregate model and publication production efficiency models, but its rank in graduate production model was 45 out of 50 . The reason behind this can be attributed to higher education provider rivalry in the HE private sector in particular, e.g., in Riyadh alone where this institution is based, alongside a giant publically owned university (KSU), there are more than 10 private HEIs which affect the number of students intake in each institution. In addition, higher and increasing tuition fees also 
negatively affect the number of graduates. More importantly, if we look at the newer HEIs, we observe that the top 10 institutions in aggregate production model are from the private sector except King Saud Bin Abdulaziz University for Health Sciences (KSAU-HS), and King Khaled University (KKU). Hence among the sample of relatively newly established institutions, private sector institutions with their advanced and better management skill set appears to be doing comparatively better.

\section{[Table 6 near here]}

The next part of the analysis is to observe trends in publications and teaching (graduate producing) efficiencies over time rather than overall averages (as done in table $5 \& 6$ ). It is worth mentioning again that the lowest value estimates represent the most efficient category of HEIs, while the highest indicate more inefficiency. The estimates contained in table 7 indicates that graduate production efficiency improved during the study period from 2008 to 2014; its peak was in 2010 for overall sector as well as for private HEIs. Moreover, there appears to be an increase in new institutions' graduate production efficiency which might be attributed to establishing more such universities all over the Kingdom, and an increase in the demand for private HEIs in recent years. The increase in private graduate production efficiency is consistent with the number of internal scholarships offered by MOE at that time. Publication production efficiency improved on average in all HE categories from 2008 to 2014 which represents a higher consideration of publications among faculty and institutions due to MOE regulations. The highest efficiency year was 2011 for both private and public institutes. For new institutions, the highest efficiency year was 2011, while 2014 was the highest efficiency year for old institutions.

[Table 7 near here] 


\section{Analysis of determinants of efficiency}

In an effort to understand the impact of an individual institution's characteristics, labour market dynamics and demand and supply related factors on efficiency, we ran a second stage regression. The dependent variable in this case was individual institution efficiency scores and seven independent variables to explain the variations in efficiencies. A number of institution specific and labor market conditions variables based on the existing empirical literature we reviewed alongside their relevance to a particular Saudi labor market in the context of Saudization policy in particular which envisages employment of local population and female education/employment are considered in this study to have a significant effect on the efficiency score of the Saudi educational institutions. Starting with institution specific variables, a dummy variables for type of ownership of institution is created and used $\left(={ }^{\prime} 1\right.$ ' if institution ownership is public owned and ' 0 ' private owned), type of institution (=' 1 ' if institution is university and ' 0 ' others such as college), age of the each institution is represented as a dummy variable $\left(={ }^{\prime} 1\right.$ ' if institution age is $>=20$ years ' 0 ' otherwise). In addition to institution specific variables, a number of variables representing labour market are considered such as percentage of working age population employed, percent of lower secondary completion, and lastly percentage of students in secondary education system who are female as well as ratio of female tertiary education academic staff. All of the above mentioned labor market variables are expected to influence the efficiency scores of the educational institutions positively in the context of increasing female workers presence and its positive impact on work place environment. The impact of ownership and age of the institution is however ambiguous and subject to debate in the empirical literature.

Simar and Wilson (2007) developed a new estimator to address the issue of potential correlation between efficiency estimates and their residuals. We utilise this estimator alongside simple OLS 
pooled regression and panel data random-effect model. We are aware of the fact that second stage regression of Simar and Wilson technique relies on the assumption of separability which implies that the explanatory variables mentioned above do not affect the efficient frontier, but may only have significant bearing on the distance of a particular institution from the efficient frontier. This strong assumption has significant implications and we are extremely thankful for an anonymous reviewer of this paper for highlighting this point. Our reasoning of following this assumption is based on two beliefs. First, environmental conditions (Saudization policy, emerging focus and push from the government to produce more graduates and publications, encouraging women participation in education sector etc.) have similar impact on all institutions. The management of some institutions would cope better and could end up doing well and form an efficient frontier for other to follow. Second, there are some alternative approaches to relax this assumption such as including environmental variables in the production set directly alongside inputs and output and constrained output subject to these environmental factors. We did not follow this approach due to scope of our study and secondly, our efficiency estimates are not that different when we used parametric stochastic frontier to estimate efficiency by incorporating environmental variables directly into production function. We do not report those estimates in this paper to avoid repetitions and an expected subsequent study using parametric estimators to be published soon.

Table 8 contains the regression coefficients of these independent variables alongside their standard errors for the three different models mentioned above. Interestingly, regression coefficients of both (pooled OLS and panel data random effect) models are insignificant except institution age. Due to well documented issues with these techniques for DEA based estimates, we focus on and discuss only estimates derived from the Simar and Wilson estimator in the following paragraphs.

[Table 8 near here] 
Interestingly, contrary to the other two estimators, regression coefficients of all variables except a dummy variable 'institution is publicly owned' are statistically significant. Looking at the institution specific variables, being a university and acquiring more than 20 years of experience has a positive impact on efficiency scores. There could be a number of reasons why universities perform better compared to colleges (medical and vocational). One of those reasons could be that there is a better research culture in universities compared to colleges and probably more resources available to spend on research and professional development. Similarly, experienced institutions are likely to recruit more students and hence have more resources to cross subsidise research activity and could also have a better stock of experienced faculty to perform and publish research. These institutions could also have learned over the time how best to utilise existing faculty in terms of time, addressing resource constraints, retention issues and incentives etc.

Looking at employment to population ratio, the coefficient is positive and statistically significant, indicating that higher employment in the economy does not promote efficiency in the Saudi HE sector. This result is perhaps linked to efforts by the faculty and top management of the institution during higher employment level periods. The ease in changing jobs or getting employment would bring job security and reduce effort level in terms of recruiting/retaining/passing more students as well as publishing more. In the context of Saudi economy, where government subsidies have been very high and created a sense of job security and inertia, this finding is in line with the existing debate on the lower efficiency of Saudi public sector employees in the region in particular.

As expected, an increase in lower secondary school completion rates would bring more students into $\mathrm{HE}$ and thus help institutions to achieve economies of scale. This would help institutions to spend more money to promote/support research related activities. This could also be said of female 
students in secondary education. Interestingly, an increase in female staff in tertiary education reduces the efficiency level of HEIs. This could perhaps be due to several reasons including:

1. Less qualified females getting into HE job market due to a significant push by the Saudi government for greater participation of Saudi in general and women in particular in the job market.

2. Due to the nature of Saudi society where women have to take care of the family as well as performing job related tasks. They may have a built-in multitasking mechanism but research activity in particular needs more attention and is an extremely time-consuming activity.

3. There could be lower expectations in terms of publication from the institution's higher management due to the above-mentioned factors and thus less weight is given to research productivity in annual performance evaluation of these particular employees.

\section{Conclusion}

This study investigates Saudi HE's management effort in utilising human resources efficiently by employing a family of non-parametric estimators. We use data on inputs (academic and administrative staff numbers) and outputs (number of graduates produced and publications listed on SCOPUS). The coverage of the sample period coincides with a significant increase in government funding for the HE sector and the emergence of the private sector in HE provision. The significance of this study is highlighted in the context of Saudi Vision 2030 where the education sector in general and HE sector in particular is very important for success. There have been some studies on the issue in a regional context, but this is the first study that has utilised an advanced method like unconditional hyperbolic $\alpha$-quantile estimator to estimate technical 
efficiency. The conclusions drawn from this study are not only relevant for the Saudi HE sector but could be generalised to the GCC countries in general due to similar economic structure, funding models and educational institutions.

By using descriptive statistics of estimated efficiencies, we conclude that different types of educational institutions are catching up in terms of efficient use of resources. On average, universities appear to be more efficient in producing graduates and contributing to knowledge advancement through publications by utilising their academic and administrative staff but the difference in performance is reducing. This finding is contrary to the widely held point of view that public sector institutions are inherently inefficient in using their resources and output maximisations. Publicly owned institutions appears to be more efficient compared to private, but the last few years of the sample period indicate convergence due to perhaps rising competition levels among public and private sectors. Vocational institutions did not start well but have been able to catch up in the later part of our sample period. In fact, they have become relatively more efficient in the last three years of the sample period.

One significant result is that newer institutions are less efficient compared to older institutions which were established 20 years ago and interestingly, we did not see the convergence of efficiency scores for these older and newer educational institutions. Lastly, some institutions are efficient in producing one particular output such as research publications compared to others who are better in producing other output such as graduates. This perhaps explains public sector old universities performing better due to established research culture and ready supply of students due to government generous scholarships schemes. 
The second stage regression results indicate that all those institutions categorized as universities appeared to be more efficient in using their resources as compared to colleges and specialist institutions. Acquiring more years of experience have also a positive impact on efficiency scores. Interestingly, supply side factors have a significant bearing on efficiencies. An increase in lower secondary completion rates and higher percentage of female students in secondary general education increases efficiencies. In terms of labour market conditions, higher employment to population ratio and increasing female academic staff ratio in tertiary education in fact reduce higher education institutional efficiencies.

\section{References}

Alabdulmenem, F. (2017). Measuring the Efficiency of Public Universities: Using Data Envelopment Analysis (DEA) to Examine Public Universities in Saudi Arabia. International Education Studies, 10(1), 137-43. doi:10.5539/ies.v10n1p137

Abbott, M., \& Doucouliagos, C. (2001). Total Factor Productivity and Efficiency in Australian Colleges of Advanced Education. Journal of Educational Administration, 39(4), 384-93. doi:10.1108/EUM0000000005497

Abbott, M., \& Doucouliagos, C. (2003). The efficiency of Australian universities: a data envelopment analysis. Economics of Education Review, 22(1), 89-97. doi:10.1016/S0272-7757(01)00068-1

Abramo, G., D'Angelo, C. A., \& Pugini, F. (2008). The Measurement of Italian Universities' Research Productivity by Means of Non-Parametric-Bibliometric Methodology. Scientometrics, 76, 225. doi:10.1007/s11192-007-1942-2

Afonso, A., \& Fernandes, S. (2008). Assessing and Explaining the Relative efficiency of Local Government. Journal of Socio-Economics, 37(5), 1946-79. doi:10.1016/j.socec.2007.03.007

Agasisti, T., \& DalBianco, A. (2006). Data envelopment analysis to the Italian university system: theoretical issues and political implications. International Journal of Business Performance, 8(4), 344-67. doi:10.1504/IJBPM.2006.009613

Agasisti, T., \& Johnes, J. (2010). Heterogeneity and the Evaluation of Efficiency: The Case of Italian Universities. Journal Applied Economics, 42(11), 1365-75. doi:10.1080/00036840701721463

Agasisti, T., \& Pérez-Esparrells, C. (2010). Comparing efficiency in a cross-country perspective: the case of Italian and Spanish state universities. Higher Education, 59(1), 85-103. doi:10.1007/s10734009-9235-8 
Agasisti, T., \& Salerno, C. (2007). Assessing the Cost Efficiency of Italian Universities. Journal Education Economics, 15(4), 455-71. doi:10.1080/09645290701273491

Al-Mutairi, K. A., \& Al-Shami, S. A. (2015). Scientific Research in Saudi Universities: Science Thrives in the Desert. Global Journal of Biology, Agriculture and Health Sciences, 4(3), 85-90. doi:10.24105/gjbahs

Alshayea, A., \& Battal, A. (2013). Evaluating the Efficiency of Faculties in Qassim University Using Data Envelopment Analysis. Journal of Business Administration and Education, 4(2), 132-38. Retrieved July 15, 2017, from http://infinitypress.info/index.php/jbae/article/view/427/226

Alshayea, A., Battal, A., \& Jarwaan, S. (2013). Total Productivity Growth in the Faculties of Anbar University using Malmquist Productivity Index. International Journal of Global Education, 2(3). Retrieved from http://www.ijtase.net/ojs/index.php/ijge/article/view/261

Arabia, G. o. (2016). Saudi Vision 2030. Retrieved July 15, 2017, from http://vision2030.gov.sa/en

Aragon, Y., Daouia, A., \& Thomas-Agnan, C. (2005). Nonparametric Frontier Estimation: A Conditional Quantile-Based Approach. Econometric Theory, 21(2), 358-89. doi:10.1017S0266466605050206

Athanassopoulos, A. D., \& Shale, E. (1997). Assessing the Comparative Efficiency of Higher Education Institutions in the UK by the Means of Data Envelopment Analysis. Journal Education Economics, 5(2), 117-34. doi:10.1080/09645299700000011

Avkiran, N. K. (2001). Investigating Technical and Scale Efficiencies of Australian Universities through Data Envelopment Analysis. Socio-Economic Planning Sciences, 35(1), 57-80. doi:10.1016/S00380121(00)00010-0

Bonaccorsi, A., Daraio, C., \& Simar, L. (2006). Advanced Indicators of Productivity of Universities an Application of Robust Nonparametric Methods to Italian Data. Scientometrics, 66(2), 389-410. doi:10.1007/s11192-006-0028-x

Bougnol, M., \& Dulá, J. H. (2006). Validating DEA as A Ranking Tool: An Application of DEA to Assess Performance in Higher Education. Annals of Operational Research, 145(1), 339-65. doi:10.1007/s10479-006-0039-2

Carrington, R., Coelli, T., \& Rao, P. (2005). The Performance of Australian Universities: Conceptual Issues and Preliminary Results. Economic Papers, 24(2), 145-63. doi:10.1111/j.17593441.2005.tb01001.x

Cazals, C., Florens, J. P., \& Simar, L. (2002). Nonparametric Frontier Estimation: A Robust Approach. Journal of econometrics, 106(1), 1-25. doi:10.1016/S0304-4076(01)00080-X

Cherchye, L., \& Abeele, P. V. (2005). On Research Efficiency: A Micro-Analysis of Dutch University Research in Economics and Business Management. Research Policy, 34(4), 495-516. doi:10.1016/j.respol.2005.03.005

Colbert, A., Levary, R. R., \& Shaner, M. C. (2000). Determining Relative Efficiency of MBA Programs Using DEA. European Journal of Operational Research, 125(3), 656-69. doi:10.1016/S03772217(99)00275-1 
Daouia, A., \& Simar, L. (2007). Nonparametric Efficiency Analysis: A Multivariate Conditional Quantile Approach. Journal of Econometrics, 140(2), 375-400. doi:10.1016/j.jeconom.2006.07.002

Deprins, D., Simar, L., \& Tulkens, H. (2006). Measuring Labor Efficiency in Post Offices. In C. Parkash, J. Drèze, C. Knox Lovell,, J. Mintz, \& C. Parkash (Ed.), In Public Goods Environmental Externalities, and Fiscal Competition (pp. 285-309). Boston, USA: Springer US. doi:10.1007/b135529

Eckles, J. E. (2010). Evaluating the Efficiency of Top Liberal Arts Colleges. Research in Higher Education, 51(3), 266-93. doi:10.1007/s11162-009-9157-4

Fandel, G. (2007). On the performance of universities in North Rhine-Westphalia, Germany: Government? Redistribution of funds judged using DEA efficiency measures. European Journal of Operational Research, 176 (1): 521-33, 176(1), 521-33. doi:10.1016/j.ejor.2005.06.043

Färe, R., Grosskopf, S., \& Knox Lovell, C. A. (1985). The Measurement of Efficiency of Production (Vol. 6). New York: Springer. doi:10.1007/978-94-015-7721-2

Ferrari, G., \& Laureti, T. (2005). Evaluating Technical Efficiency of Human Capital Formation in the Italian University: Evidence from Florence. Statistical Methods and Applications, 14(2), 243-70. doi:10.1007/s10260-005-0109-7

Flegg, A. T., Allen, D. O., Field, K., \& Thurlow, T. W. (2004). Measuring the Efficiency of British Universities: A Multi-Period Data Envelopment Analysis. Journal Education Economics, 12(3), 231-49. Retrieved from http://www.tandfonline.com/10.1080/0904529042000258590

Foltz, J., Barham, B., Chavas, J., \& Kim, K. (2012). Efficiency and technological change at US research universities. Journal of Productivity Analysis, 37(2), 171-86. doi:10.1007/s11123-011-0249-8

Førsund, F. R., \& Kalhagen, K. O. (1999). Efficiency and Productivity of Norwegian Colleges. University of Oslo, Department of Economics. Blindern: Frisch Centre. Retrieved from http://www.sv.uio.no/econ/english/research/unpublished-works/working-papers/pdffiles/1999/Memo-11-1999.pdf

Ghulam, Y., \& Jaffry, S. (2015). Efficiency and Productivity of the Cement Industry: Pakistani Experience of Deregulation and Privatization. Omega, 54, 101-15. doi:10.1016/j.omega.2015.01.013

Glass, J., McCallion, G., McKillop, D., Rasaratnam, S., \& Stringer, K. (2006). Implications of Variant Efficiency Measures for Policy Evaluations in UK Higher Education. Socio-economic planning sciences, 40(2), 119-42. doi:10.1016/j.seps.2004.10.004

Izadi, H., Johnes, G., Oskrochi, R., \& Crouchley, R. (2002). Stochastic Frontier Estimation of A CES Cost Function: The Case of Higher Education in Britain. Economics of Education Review, 21(1), 63-71. doi:10.1016/S0272-7757(00)00044-3

Johnes, J. (2006). Data envelopment analysis and its application to the measurement of efficiency in higher education. Economics of Education Review, 25(3), 273-88. doi:10.1016/j.econedurev.2005.02.005 
Johnes, J. (2008). Efficiency and Productivity Change in the English Higher Education Sector from 1996/07 to 2002/03. The Manchester School, 76(6), 653-74. Retrieved from http://eprints.lancs.ac.uk/45010/1/10.pdf

Johnes, J., \& Johnes, G. (1995). Research Funding and Performance in U.K. University Departments of Economics: A Frontier Analysis. Economics of Education Review, 14(3), 301-14. doi:10.1016/0272-7757(95)00008-8

Kantabutra, S., \& Tang, J. C. (2010). Efficiency analysis of public universities in Thailand. Tertiary Education and Management, 16(1), 15-33. doi:10.1080/13583881003629798

Kao, C., \& Hung, H. (2008). Efficiency Analysis of University Departments: An Empirical Study. Omega, 36(4), 653-64. doi:10.1016/j.omega.2006.02.003

Kempkes, G., \& Pohl, C. (2010). The Efficiency of German Universities: Some Evidence from Nonparametric and Parametric Methods. Applied Economics, 42(16), 2063-79. doi:10.1080/00036840701765361

Korhonen, P., Tainio, R., \& Wallenius, J. (2001). Value Efficiency Analysis of Academic Research. European Journal of Operational Research, 130(1), 121-32. doi:10.1016/S0377-2217(00)00050-3

Kuo, J. S., Kuo, C. S., \& Ho, Y. C. (2005). Relative Efficiencies of Public and Private Institutions of Learning in Taiwan. The Annual Meeting of the Public Choice Society. New Orleans, Louisiana.

Leitner, K.-H., Prikoszovits, J., Schaffhauser-Linzatti, M., Stowasser, R., \& Wagner, K. (2007). The impact of size and specialisation on universities' department performance: A DEA analysis applied to Austrian universities. Higher Education, 53(4), 517-38. doi:10.1007/s10734-006-0002-9

McMillan, M., \& Datta, D. (1998). The Relative Efficiencies of Canadian Universities: A DEA Perspective. Canadian Public Policy, 24(4), 485-511. doi:10.2307/3552021

Moreno, A. A., \& Tadepalli, R. (2002). Assessing Academic Department Efficiency at a Public University. Managerial and Decisions Economics, 23(7), 385-93. doi:10.1002/mde.1075

Sarrico, C. S., \& Dyson, R. G. (2000). Using Data Envelopment Analysis for Planning in UK Universities An Institutional Perspective. Journal of the Operational Research Society, 51(7), 789-800. doi:10.2307/253960

SAV, T. (2012). Productivity Growth and Efficiency Changes in Publicly Managed U.S. Comprehensive Universities: Data Envelopment Analysis and Malmquist Decompositions. Journal of Business Management and Applied Economics, 1(4). Retrieved July 15, 2017, from http://corescholar.libraries.wright.edu/econ/90

Selim, S., \& Bursalioglu, S. (2013). Analysis of the Determinants of Universities Efficiency in Turkey: Application of the Data Envelopment Analysis and Panel Tobit Model. Procedia - Social and Behavioral Sciences, 89, 895-900. doi:10.1016/j.sbspro.2013.08.952

Shepherd, R. (1970). Theory of Cost and Production Functions. New Jersey: Princeton University Press. 
Simar, L., \& Wilson, P. W. (2007). Estimation and inference in two-stage, semi-parametric models of production processes. Journal of Econometrics, 136(1), 31-64.

doi:10.1016/j.jeconom.2005.07.009

Stocia, M., \& Aldea, A. (2016). Efficiency of Teaching and Research Activities in Romanian Universities: An Order-Alpha Partial Frontiers Approach. Economic Computation and Economic Cybernetics Studies and Research, 50(4), 169-86. Retrieved from http://www.ecocyb.ase.ro/nr20164/11\%20-\%20Stoica\%20Madalina,\%20final.pdf

Tommaso, A., \& Bianco, A. (2006). Data Envelopment Analysis to the Italian University System: Theoretical Issues and Policy Implications. International Journal of Business Performance Management, 8(4), 344-67. doi:10.1504/IJBPM.2006.009613

Warning, S. (2004). Performance Differences in German Higher Education: Empirical Analysis of Strategic Group. Review of Industrial Organization, 24(4), 393-408. doi:10.1023/B:REIO.0000037538.48594.2c

Wheelock , D. C., \& Wilson, P. W. (2003). Robust Nonparametric Estimation of Efficiency and Technical Change in U.S. Commercial Banking . WORKING PAPER SERIES, Working Paper 2003-037A. FEDERAL RESERVE BANK OF ST. LOUIS . Retrieved from https://research.stlouisfed.org/wp/2003/2003-037.pdf

Wheelock, D. C., \& Wilson P. W., P. W. (2009). Robust Nonparametric Quantile Estimation of Efficiency and Productivity Change in US Commercial Banking. 1985-2004. Journal of Business and Economic Statistics 27(3): 354-68., 27(3), 354-68. doi:10.1198/jbes.2009.06145

Wheelock, D. C., \& Wilson, P. W. (2008). Non-parametric, unconditional quantile estimation for efficiency analysis with an application to Federal Reserve check processing operations. Journal of Econometrics, 145(1-2), 209-25. doi:10.1016/j.jeconom.2008.05.007

Wilson, P. W. (2008). FEAR: A software package for frontier efficiency analysis with R. Socio-economic planning sciences, 42(4), 247-54. doi:10.1016/j.seps.2007.02.001

Wolszczak-Derlacz, J., \& Parteka, A. (2010). Scientific productivity of public higher education institutions in Poland: A comperative bibliometric analysis. Warsaw: Ernst \& Young Polska. Retrieved from http://www.ey.com/Publication/vwLUAssets/Scientific_productivity.pdf/\$FILE/Scientific_produc tivity.pdf

Wolszczak-Derlacz, J., \& Parteka, A. (2011). Efficiency of European Public Higher Education Institutions: A Two-Stage Multi-Country Approach . DOI:. Scientometrics, 89, 887. doi:10.1007/s11192-0110484-9

Worthington, A. C., \& Lee, B. L. (2008). Efficiency, Technology and Productivity Change in Australian Universities, 1998-2003. Economics of Education Review, 27(3), 285-98.

doi:10.1016/j.econedurev.2006.09.012 


\section{Tables}

Table 1: Selective empirical studies using DEA to evaluate the efficiency of Higher Education Institutions

\begin{tabular}{|c|c|c|c|c|c|c|}
\hline Reference & Country & $\begin{array}{l}\text { Sample of } \\
\text { HEIs }\end{array}$ & $\begin{array}{l}\text { Data/ } \\
\text { Years }\end{array}$ & Inputs & Outputs & Main Conclusions \\
\hline $\begin{array}{l}\text { Athanassopoulos } \\
\text { and Shale (1997) }\end{array}$ & UK & 45 Univ. & 1992-93 & 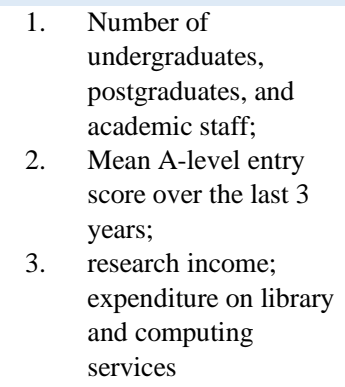 & $\begin{array}{l}\text { 1. Number of successful leavers; } \\
\text { 2. Number of higher degrees } \\
\text { 3. }\end{array}$ & $\begin{array}{l}\text { Universities are clustered into } 3 \text { main groups: } \\
\text { Low cost and high outcome efficiency; high cost } \\
\text { and low outcome efficiency; } \\
\text { high cost and high outcome efficiency; }\end{array}$ \\
\hline $\begin{array}{l}\text { Worthington and } \\
\text { Lee (2008) }\end{array}$ & UK & 112 HEIs & $\begin{array}{l}1997- \\
2005\end{array}$ & $\begin{array}{ll}\text { 1. } & \begin{array}{l}\text { Number of full-time } \\
\text { undergraduate and } \\
\text { postgraduate enrolled } \\
\text { students, }\end{array} \\
\text { 2. } & \text { Academic staff, } \\
\text { 3. } & \text { Administrative } \\
\text { 4. } & \begin{array}{l}\text { Expenditures, } \\
\text { expenditures on } \\
\text { centralized academic } \\
\text { services }\end{array}\end{array}$ & $\begin{array}{l}\text { 1. Degrees awarded (graduate and } \\
\text { postgraduate), } \\
\text { 2. Research income received }\end{array}$ & $\begin{array}{l}\text { HEI's have experienced productivity growth of } \\
1 \% \text { p.a., due to technological progress of } 6 \% \\
\text { coupled with a decrease in technical efficiency of } \\
5 \% \text {. } \\
\text { Rapid changes in the higher education sector } \\
\text { contributed in improving the technology of } \\
\text { production but this has been accompanied by a } \\
\text { reduction of technical efficiency. }\end{array}$ \\
\hline $\begin{array}{l}\text { Agasisti and Perez- } \\
\text { Esparrells (2010) }\end{array}$ & Italy and Spain & $\begin{array}{l}57 \text { Italian } \\
\text { and } 46 \\
\text { Spanish } \\
\text { Public Univ. }\end{array}$ & 2004-05 & $\begin{array}{l}\text { 1. Number of students, } \\
\text { 2. Number of PhD students, } \\
\text { 3. Number of professors, } \\
\text { 4. Financial resources }\end{array}$ & $\begin{array}{l}\text { 1. Number of graduates; } \\
\text { 2. Amount of external resources } \\
\text { attracted to research activities }\end{array}$ & $\begin{array}{l}\text { In Italy, the improvement of performance over } \\
\text { time was due to major "technological changes", } \\
\text { while in Spain it was due to "pure" efficiency } \\
\text { (arising from new funding models) }\end{array}$ \\
\hline Eckles (2010) & USA; 27 States & $\begin{array}{l}93 \text { private } \\
\text { liberal arts } \\
\text { colleges }\end{array}$ & 2006-07 & $\begin{array}{ll}\text { 1. } & \text { Cost per } \\
\text { undergraduate, } \\
\text { 2. } \\
\text { Fulltime faculty (\%), } \\
\text { Students in the top } \\
10 \% \text { of their high } \\
\text { school class (\%) } \\
\text { 4. } 25^{\text {th }} \text { percentile of } \\
\text { entering students' SAT } \\
\text { scores }\end{array}$ & Six-year graduation rate & $\begin{array}{l}18 \text { colleges are found to be technically efficient. } \\
\text { Among these, it is possible to identify peers for } \\
\text { each of the technically inefficient institutions }\end{array}$ \\
\hline
\end{tabular}




\begin{tabular}{|c|c|c|c|c|c|c|}
\hline Reference & Country & $\begin{array}{l}\text { Sample of } \\
\text { HEIs }\end{array}$ & $\begin{array}{l}\text { Data/ } \\
\text { Years }\end{array}$ & Inputs & Outputs & Main Conclusions \\
\hline $\begin{array}{l}\text { Kantabutra and } \\
\text { Tang (Kantabutra } \\
\& \text { Tang, 2010) }\end{array}$ & Thailand & $\begin{array}{l}22 \text { Public } \\
\text { Univ.; } \\
267 \text { Faculties }\end{array}$ & 2003-06 & $\begin{array}{l}\text { Teaching Efficiency } \\
\underline{\text { Model }} \\
\text { 1. Annual operating } \\
\quad \text { budget; } \\
\text { 2. No. of academic staff; } \\
\text { 3. No. of non-academic } \\
\quad \text { staff. } \\
\text { Research Efficiency Model } \\
\begin{array}{l}\text { Authors used amount of } \\
\text { internal and external } \\
\text { research fund }\end{array}\end{array}$ & $\begin{aligned} \text { Teaching Efficiency Model } \\
\begin{array}{l}\text { 1. } \\
\text { No. of graduates at the } \\
\text { undergraduate/ master } \\
\text { degree levels; }\end{array} \\
\text { 2. } \begin{array}{l}\text { Employment rate } \\
\text { Research Efficiency Model }\end{array} \\
\begin{array}{l}\text { No. of publications in } \\
\text { internationally/nationally } \\
\text { refereed journals, } \\
\text { No. of PhD degrees }\end{array}\end{aligned}$ & $\begin{array}{l}\text { Public universities in Thailand were more } \\
\text { efficient in teaching than in research. } \\
\text { Faculties in health sciences were more efficient } \\
\text { compared to others. }\end{array}$ \\
\hline $\begin{array}{l}\text { Kempkes and Pohl } \\
\text { (2010) }\end{array}$ & Germany & $\begin{array}{l}72 \text { Public } \\
\text { Univ. }\end{array}$ & $\begin{array}{l}1998- \\
2003\end{array}$ & $\begin{array}{l}\text { 1. Faculty composition } \\
\text { 2. No. of technical } \\
\text { personnel; } \\
\text { 3. No. of research } \\
\text { personnel; } \\
\text { 4. Current expenditure. }\end{array}$ & $\begin{array}{l}\text { 1. No. of graduates } \\
\text { 2. Amount of research grants }\end{array}$ & $\begin{array}{l}\text { Although East German universities performed } \\
\text { better in terms of total factor productivity change } \\
\text { but West Germany universities were still better } \\
\text { over the whole sample period in terms of relative } \\
\text { efficiency. }\end{array}$ \\
\hline $\begin{array}{l}\text { Agasisti and Johnes } \\
\text { (2010) }\end{array}$ & Italy & $\begin{array}{l}57 \text { public } \\
\text { Univ. }\end{array}$ & 2002-04 & Costs $€$ & $\begin{array}{l}\text { 1. No. of student } \\
\text { 2. No. of research activity }\end{array}$ & $\begin{array}{l}\text { There are universities in Italy that are too big; } \\
\text { they have exhausted scale and scope economies, } \\
\text { and are experiencing diseconomies owing to their } \\
\text { size. }\end{array}$ \\
\hline $\begin{array}{l}\text { Wolszczak - } \\
\text { Derlacz and Parteka } \\
\text { (2011) }\end{array}$ & $\begin{array}{l}\text { Austria, } \\
\text { Finland, } \\
\text { Germany, Italy, } \\
\text { Poland, UK, } \\
\text { and } \\
\text { Switzerland }\end{array}$ & $\begin{array}{l}259 \text { Public } \\
\text { Univ. }\end{array}$ & 2001-05 & $\begin{array}{l}\text { 1. Total academic staff; } \\
\text { 2. Total number of } \\
\text { students; } \\
\text { 3. Total revenues. }\end{array}$ & $\begin{array}{ll}\text { 1. No. of graduations, } \\
\text { 2. } \begin{array}{l}\text { No. of scientific } \\
\text { publications. }\end{array}\end{array}$ & $\begin{array}{l}\text { Only } 5 \% \text { of HEI's were fully efficient; } \\
\text { Universities of Switzerland obtained the best } \\
\text { efficiency scores. Second stage regression results } \\
\text { confirmed that found evidence that a higher share } \\
\text { of funding from external sources and an increase } \\
\text { in the number of females' faculty members } \\
\text { improve the efficiency of the institution. } \\
\text { Similarly, the presence of medical faculty reduces } \\
\text { inefficiency of the institution }\end{array}$ \\
\hline Foltz et al (2012) & USA & $\begin{array}{l}61 \text { Public } \\
\text { and } 31 \\
\text { Private } \\
\text { Research } \\
\text { Univ. }\end{array}$ & $\begin{array}{l}1981- \\
1998\end{array}$ & $\begin{array}{l}\text { 1. Faculty, } \\
\text { 2. postdoctoral } \\
\text { researchers, } \\
\text { 3. PhD graduate students }\end{array}$ & $\begin{array}{l}\text { 1. Journal articles, } \\
\text { 2. Patents, } \\
\text { 3. Trained undergraduate } \\
\text { students, } \\
\text { 4. Trained graduate students }\end{array}$ & $\begin{array}{l}\text { Public universities are more efficient than private } \\
\text { universities. } \\
\text { Larger universities are significantly more } \\
\text { inefficient than smaller universities. }\end{array}$ \\
\hline
\end{tabular}




$\begin{array}{lcccc}\text { Reference } & \text { Country } & \text { Sample of } & \text { Data/ } & \text { Inputs } \\ & \text { HEIs } & \text { Years } & & \text { Outputs }\end{array}$

We found that total research funding tends to increase efficiency.

\begin{tabular}{|c|c|c|c|c|c|c|c|}
\hline Sav (2012) & USA & $\begin{array}{l}247 \\
\text { universities }\end{array}$ & 2006-09 & & $\begin{array}{ll}\text { 5. } & \text { Employed, \# } \\
\text { 6. } & \text { Aculty Salary, \$ } \\
& \text { Support, } \$ \\
\text { 7. } & \text { Academic } \\
& \text { Buildings, } \$ \\
\text { 8. } & \text { Equipment, \$ } \\
\text { 9. } & \text { Auxiliary } \\
& \text { Buildings, \$ }\end{array}$ & $\begin{array}{l}1 . \\
2 . \\
3 .\end{array}$ & $\begin{array}{l}\text { Undergraduate Edu., Cr. Hrs., } \\
\text { Graduate Edu., Cr. Hrs., } \\
\text { Research, \$. }\end{array}$ \\
\hline $\begin{array}{l}\text { Alshayea et al. } \\
\text { (2013) }\end{array}$ & Iraq & $\begin{array}{l}19 \text { faculties } \\
\text { of Anbar } \\
\text { Univ., AU }\end{array}$ & 2011-12 & $\begin{array}{l}1 . \\
2 .\end{array}$ & $\begin{array}{l}\text { Academic Staff } \\
\text { General staff }\end{array}$ & $\begin{array}{l}1 . \\
2 .\end{array}$ & $\begin{array}{l}\text { No. of graduates } \\
\text { No. of research publications }\end{array}$ \\
\hline $\begin{array}{l}\text { Shayea and Battal } \\
\text { (2013) }\end{array}$ & Saudi Arabia & $\begin{array}{l}18 \text { Faculties } \\
\text { in Qasim } \\
\text { Univ., FQU }\end{array}$ & 2011-12 & $\begin{array}{l}1 . \\
2 .\end{array}$ & $\begin{array}{l}\text { No. of students } \\
\text { enrolled, } \\
\text { No. of teachers and staff }\end{array}$ & 1. & $\begin{array}{l}\text { No. of students with a bachelor's } \\
\text { degree } \\
\text { No. of research }\end{array}$ \\
\hline $\begin{array}{l}\text { Selim and } \\
\text { Bursalioglu (2013) }\end{array}$ & Turkey & 51 HEIs & 2006-10 & $\begin{array}{l}2 . \\
3 .\end{array}$ & $\begin{array}{l}\text { Central government } \\
\text { budget appropriations } \\
\text { own revenue, } \\
\text { Project allocations, } \\
\text { Total academic. }\end{array}$ & $\begin{array}{l}2 . \\
3 .\end{array}$ & $\begin{array}{l}\text { No. of graduate, postgraduate and } \\
\text { doctorate students, } \\
\text { No. of publications. } \\
\text { No. of employment }\end{array}$ \\
\hline
\end{tabular}

Universities experienced an annual productivity decline of $4 \%$ due to technological regress despite improvement in efficiency (pure as well as scale) during the sample period.

Efficiency gains were perhaps due to financial crisis

$73.7 \%$ of faculties are efficient. In terms of total factor productivity, faculties of A.U. obtained an index score of 0.879 , which means that $36.8 \%$ saw remarkable productivity growth. The technological index shows that $10.5 \%$ only shows a technological progress.

(10) FQU or $55.5 \%$ are efficient with average 0.88 in term of variable return to scale efficiency

FQU obtained average scale efficiency 0.68 and only three FQU get the optimum size.

Central government budget appropriations has a negative effect on efficiency 


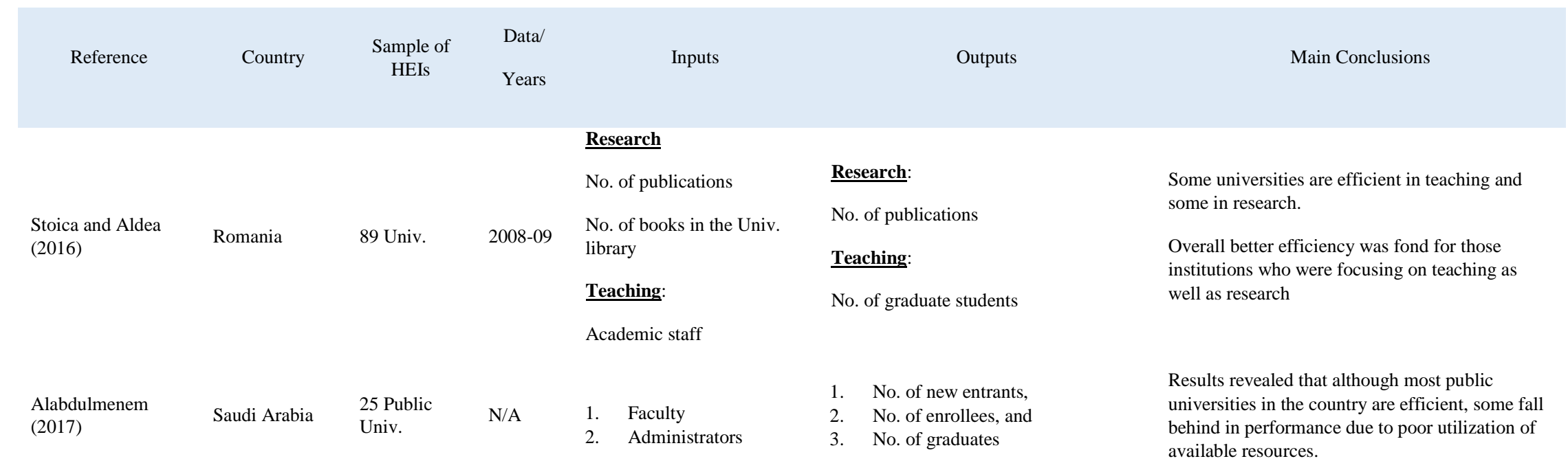

* Studies are presented in chronological order 
Table 2: Descriptive Statistics

\begin{tabular}{|c|c|c|c|c|c|c|c|c|}
\hline & Mean & Min & Max & $\mathrm{Cv}$ & Public Inst. & Private Inst. & Old Inst. & New Inst. \\
\hline & & & & & Mean & Mean & mean & mean \\
\hline Academic staff & 973.41 & 11.00 & 7889.00 & 1.54 & 203.28 & 99.52 & 2258.50 & 592.65 \\
\hline Administrative staff & 855.18 & 6.00 & 26775.00 & 2.54 & 133.88 & 89.84 & 2106.07 & 484.55 \\
\hline Number of graduates & 2517.24 & 1.00 & 24675.00 & 1.68 & 572.59 & 160.19 & 5983.89 & 1490.09 \\
\hline \multirow[t]{3}{*}{ Publications } & 153.80 & 1.00 & 5119.00 & 3.58 & 1.00 & 14.34 & 507.20 & 49.08 \\
\hline & 2008 & 2009 & 2010 & 2011 & 2012 & 2013 & 2014 & overall \\
\hline & & & & & Public & & & \\
\hline graduates/academic staff & 1.91 & 1.23 & 1.64 & 2.15 & 2.05 & 1.57 & 1.88 & 1.75 \\
\hline publications/academic staff & 0.02 & 0.02 & 0.03 & 0.04 & 0.05 & 0.06 & 0.07 & 0.04 \\
\hline \multirow[t]{2}{*}{ graduates/administrative staff } & 3.67 & 2.35 & 3.24 & 3.20 & 2.84 & 1.75 & 2.32 & 2.66 \\
\hline & & & & & Private & & & \\
\hline graduates/academic staff & 0.29 & 0.24 & 0.25 & 0.31 & 0.66 & 1.23 & 0.91 & 0.48 \\
\hline publications/academic staff & 0.06 & 0.06 & 0.06 & 0.05 & 0.05 & 0.05 & 0.05 & 0.05 \\
\hline \multirow[t]{2}{*}{ graduates/administrative staff } & 0.30 & 0.28 & 0.25 & 0.35 & 0.77 & 1.26 & 1.05 & 0.53 \\
\hline & & & & & New & & & \\
\hline graduates/academic staff & 0.68 & 0.61 & 0.51 & 0.65 & 1.03 & 1.24 & 1.16 & 0.82 \\
\hline publications/academic staff & 0.04 & 0.04 & 0.04 & 0.04 & 0.05 & 0.06 & 0.05 & 0.05 \\
\hline \multirow[t]{2}{*}{ graduates/administrative staff } & 1.03 & 0.93 & 0.73 & 0.84 & 1.26 & 1.27 & 1.37 & 1.05 \\
\hline & & & & & Old & & & \\
\hline graduates/academic staff & 1.67 & 0.59 & 1.93 & 2.01 & 2.22 & 2.21 & 2.30 & 1.71 \\
\hline publications/academic staff & 0.02 & 0.02 & 0.03 & 0.04 & 0.04 & 0.07 & 0.09 & 0.04 \\
\hline graduates/administrative staff & 2.18 & 0.90 & 3.14 & 2.65 & 3.30 & 2.82 & 2.92 & 2.39 \\
\hline
\end{tabular}




\begin{tabular}{|c|c|c|c|c|c|c|c|}
\hline & 2008 & 2009 & 2010 & 2011 & 2012 & 2013 & 2014 \\
\hline FDH efficiency estimates - input oriented & 1.309 & 1.168 & 1.129 & 1.237 & 1.164 & 1.207 & 1.152 \\
\hline FDH efficiency estimates - output oriented & 0.851 & 0.899 & 0.881 & 0.930 & 0.797 & 0.797 & 0.770 \\
\hline DEA efficiency estimates - input oriented & 1.991 & 1.853 & 1.797 & 2.415 & 2.002 & 2.462 & 2.048 \\
\hline DEA efficiency estimates - output oriented & 0.311 & 0.392 & 0.339 & 0.270 & 0.377 & 0.316 & 0.394 \\
\hline DEA efficiency estimates - hyperbolic graph & 1.593 & 1.467 & 1.443 & 1.732 & 1.499 & 1.649 & 1.482 \\
\hline Order-m efficiency estimates - input oriented & 0.758 & 0.667 & 0.648 & 0.667 & 0.645 & 0.632 & 0.623 \\
\hline Order-m efficiency estimates - output oriented & 0.401 & 0.323 & 0.300 & 0.349 & 0.326 & 0.323 & 0.278 \\
\hline Conditional alpha-quantile efficiency estimates - input oriented & 0.590 & 0.474 & 0.506 & 0.495 & 0.518 & 0.477 & 0.461 \\
\hline Conditional alpha-quantile efficiency estimates -output oriented & 3.578 & 3.060 & 3.269 & 3.519 & 2.745 & 2.666 & 2.779 \\
\hline Unconditional alpha-quantile efficiency estimates - hyperbolic graph & 0.314 & 0.323 & 0.322 & 0.312 & 0.365 & 0.341 & 0.331 \\
\hline
\end{tabular}

Table 4: Heterogeneity in HEls efficiency estimates

\begin{tabular}{|c|c|c|c|c|c|c|c|c|}
\hline & 2008 & 2009 & 2010 & 2011 & 2012 & 2013 & 2014 & overall \\
\hline Overall & 0.314 & 0.323 & 0.322 & 0.312 & 0.365 & 0.341 & 0.331 & 0.330 \\
\hline College & 0.420 & 0.369 & 0.401 & 0.369 & 0.422 & 0.383 & 0.349 & 0.386 \\
\hline university & 0.269 & 0.301 & 0.281 & 0.283 & 0.330 & 0.315 & 0.318 & 0.300 \\
\hline Private & 0.328 & 0.287 & 0.321 & 0.306 & 0.401 & 0.380 & 0.353 & 0.340 \\
\hline Public & 0.304 & 0.354 & 0.324 & 0.318 & 0.337 & 0.312 & 0.313 & 0.322 \\
\hline general & 0.268 & 0.297 & 0.303 & 0.303 & 0.349 & 0.330 & 0.331 & 0.312 \\
\hline medical & 0.390 & 0.345 & 0.378 & 0.339 & 0.434 & 0.391 & 0.358 & 0.376 \\
\hline vocational & 0.590 & 0.496 & 0.363 & 0.329 & 0.351 & 0.320 & 0.281 & 0.370 \\
\hline new inst. & 0.320 & 0.312 & 0.350 & 0.330 & 0.404 & 0.377 & 0.367 & 0.353 \\
\hline old inst. & 0.297 & 0.353 & 0.244 & 0.254 & 0.254 & 0.237 & 0.226 & 0.263 \\
\hline
\end{tabular}


Table 5: Rankings of Saudi HEIs

\begin{tabular}{|c|c|c|c|c|c|c|}
\hline University/college & $\begin{array}{l}\text { Aggregate } \\
\text { production } \\
\text { efficiency }\end{array}$ & $\begin{array}{l}\text { Graduate } \\
\text { production } \\
\text { efficiency }\end{array}$ & $\begin{array}{l}\text { Publication } \\
\text { production } \\
\text { efficiency }\end{array}$ & $\begin{array}{l}\text { Aggregate } \\
\text { production } \\
\text { ranking }\end{array}$ & $\begin{array}{l}\text { Graduate } \\
\text { production } \\
\text { ranking }\end{array}$ & $\begin{array}{c}\text { Publication } \\
\text { production } \\
\text { ranking }\end{array}$ \\
\hline KSU & 0.060 & 0.597 & 0.064 & 1 & 42 & 1 \\
\hline Alfaisal University & 0.080 & 0.942 & 0.080 & 2 & 58 & 2 \\
\hline KAU & 0.103 & 0.380 & 0.130 & 3 & 11 & 3 \\
\hline KFUPM & 0.147 & 0.906 & 0.155 & 4 & 57 & 4 \\
\hline Fakeeh College for Medical Sciences & 0.181 & 0.173 & 0.385 & 5 & 1 & 15 \\
\hline Prince Sultan University & 0.182 & 0.542 & 0.202 & 6 & 29 & 5 \\
\hline Arab Open University & 0.211 & 0.272 & 0.860 & 7 & 4 & 48 \\
\hline IBN Rushd College For Management Science & 0.212 & 0.233 & 0.458 & 8 & 2 & 22 \\
\hline Saad College of Nursing and Allied Health & 0.215 & 0.543 & 0.215 & 9 & 30 & 6 \\
\hline Al-Baha Private College of Science & 0.249 & 0.254 & 0.648 & 10 & 3 & 38 \\
\hline KSAU-HS & 0.254 & 0.584 & 0.271 & 11 & 39 & 7 \\
\hline King Faisal University & 0.262 & 0.585 & 0.316 & 12 & 40 & 8 \\
\hline TVTC & 0.271 & 0.292 & 3.539 & 13 & 5 & 60 \\
\hline Al-Riyada College for Health Sciences & 0.273 & 0.298 & 0.336 & 14 & 6 & 10 \\
\hline KKU & 0.277 & 0.531 & 0.417 & 15 & 28 & 18 \\
\hline Al Baha University & 0.281 & 0.355 & 0.604 & 16 & 8 & 34 \\
\hline Yanbu University College & 0.287 & 0.676 & 0.318 & 17 & 51 & 9 \\
\hline Yanbu Industrial College & 0.293 & 0.468 & 0.356 & 18 & 19 & 12 \\
\hline Prince Mohammad Bin Fahd University & 0.296 & 0.721 & 0.350 & 19 & 52 & 11 \\
\hline Taif University & 0.303 & 0.494 & 0.453 & 20 & 21 & 21 \\
\hline University of Business and Technology & 0.310 & 0.472 & 0.484 & 21 & 20 & 23 \\
\hline Taibah University & 0.313 & 0.441 & 0.492 & 22 & 17 & 24 \\
\hline Ibn Sina National College for Medical St & 0.313 & 0.566 & 0.379 & 23 & 37 & 14 \\
\hline Najran University & 0.316 & 0.404 & 0.430 & 24 & 13 & 19 \\
\hline Shagra University & 0.322 & 0.421 & 0.557 & 25 & 15 & 31 \\
\hline Ha'il University & 0.322 & 0.416 & 0.502 & 26 & 14 & 26 \\
\hline Fahd Bin Sulltan University & 0.325 & 0.362 & 0.615 & 27 & 10 & 37 \\
\hline Islamic University & 0.331 & 0.622 & 0.412 & 28 & 44 & 17 \\
\hline Arab East Colleges for Postgraduate Stud & 0.342 & 0.346 & 0.411 & 29 & 7 & 16 \\
\hline Sulaiman Alrajhi Colleges & 0.357 & 0.360 & 0.357 & 30 & 9 & 13 \\
\hline Dar Al Uloom University & 0.365 & 0.673 & 0.432 & 31 & 50 & 20 \\
\hline UmmAl-Qura University & 0.366 & 0.496 & 0.711 & 32 & 24 & 40 \\
\hline Northern Borders University & 0.370 & 0.447 & 0.797 & 33 & 18 & 46 \\
\hline Al Yamamah University & 0.375 & 0.596 & 0.593 & 34 & 41 & 33 \\
\hline Qassim University & 0.383 & 0.558 & 0.724 & 35 & 35 & 42 \\
\hline Qassim Private Colleges & 0.387 & 0.399 & 0.613 & 36 & 12 & 36 \\
\hline Jazan University & 0.405 & 0.506 & 0.800 & 37 & 25 & 47 \\
\hline Jubail Industrial College & 0.417 & 0.563 & 0.749 & 38 & 36 & 44 \\
\hline Al Jouf University & 0.417 & 0.513 & 0.544 & 39 & 26 & 29 \\
\hline Riyadh College of Dentistry and Pharmacy & 0.433 & 0.638 & 0.689 & 40 & 46 & 39 \\
\hline Effat University & 0.441 & 0.643 & 0.566 & 41 & 47 & 32 \\
\hline University of Dammam & 0.454 & 0.664 & 0.871 & 42 & 48 & 49 \\
\hline Almajmaah University & 0.457 & 0.547 & 1.145 & 43 & 31 & 55 \\
\hline Prince Sultan Military College of Health & 0.462 & 0.576 & 0.774 & 44 & 38 & 45 \\
\hline Jubail University College & 0.465 & 0.771 & 0.520 & 45 & 53 & 28 \\
\hline University of Tabuk & 0.467 & 0.425 & 1.902 & 46 & 16 & 58 \\
\hline Prince Sultan College for Business & 0.489 & 0.495 & 0.714 & 47 & 22 & 41 \\
\hline Salman Bin Abdulaziz University & 0.490 & 0.865 & 0.726 & 48 & 54 & 43 \\
\hline Al-Farabi College for Medicine, Dentistry & 0.494 & 0.867 & 0.494 & 49 & 55 & 25 \\
\hline Jubail Technical Institute & 0.496 & 0.496 & 1.000 & 50 & 23 & 54 \\
\hline Dar Al-Hekma University & 0.508 & 0.608 & 0.898 & 51 & 43 & 51 \\
\hline Saudi Electronic University & 0.509 & 1.218 & 0.509 & 52 & 60 & 27 \\
\hline Mohammad Al-mana College for Health Science & 0.526 & 0.515 & 0.607 & 53 & 27 & 35 \\
\hline Al-Imam Mohammad Bin Saud Islamic University & 0.540 & 0.552 & 4.140 & 54 & 33 & 61 \\
\hline Princess Nora bint Abdulrahman University & 0.547 & 0.557 & 2.409 & 55 & 34 & 59 \\
\hline Inaya Medical College & 0.549 & 0.549 & 0.549 & 56 & 32 & 30 \\
\hline Institute of Public Administration & 0.556 & 0.632 & 1.390 & 57 & 45 & 56 \\
\hline Buraydah Collages & 0.628 & 0.667 & 0.889 & 58 & 49 & 50 \\
\hline Batterjee Medical College & 0.827 & 0.882 & 0.990 & 59 & 56 & 53 \\
\hline Al-Ghad International College for Applied & 0.959 & 1.533 & 1.427 & 60 & 61 & 57 \\
\hline Al Maarefa College for Science and Technology & 0.962 & 1.145 & 0.981 & 61 & 59 & 52 \\
\hline
\end{tabular}


Table 6: Rankings of Saudi HEls based on age of the institutions

\begin{tabular}{|c|c|c|c|c|c|c|}
\hline University/college & $\begin{array}{l}\text { Aggregate } \\
\text { production } \\
\text { efficiency }\end{array}$ & $\begin{array}{l}\text { Graduate } \\
\text { production } \\
\text { efficiency }\end{array}$ & $\begin{array}{l}\text { Publication } \\
\text { production } \\
\text { efficiency }\end{array}$ & $\begin{array}{c}\text { Aggregate } \\
\text { production } \\
\text { ranking }\end{array}$ & $\begin{array}{c}\text { Graduate } \\
\text { production } \\
\text { ranking }\end{array}$ & $\begin{array}{c}\text { Publication } \\
\text { production } \\
\text { ranking }\end{array}$ \\
\hline \multicolumn{7}{|c|}{ Old institutions } \\
\hline KSU & 0.060 & 0.597 & 0.064 & 1 & 10 & 1 \\
\hline KAU & 0.103 & 0.380 & 0.130 & 2 & 2 & 2 \\
\hline KFUPM & 0.147 & 0.906 & 0.155 & 3 & 13 & 3 \\
\hline Yanbu Industrial College & 0.260 & 0.410 & 0.326 & 4 & 3 & 5 \\
\hline King Faisal University & 0.262 & 0.585 & 0.316 & 5 & 9 & 4 \\
\hline TVTC & 0.271 & 0.292 & 3.539 & 6 & 1 & 12 \\
\hline Ibn Sina National College for Medical St & 0.313 & 0.566 & 0.379 & 7 & 7 & 6 \\
\hline Islamic University & 0.331 & 0.622 & 0.412 & 8 & 11 & 7 \\
\hline Jubail Industrial College & 0.350 & 0.462 & 0.707 & 9 & 4 & 8 \\
\hline UmmAl-Qura University & 0.366 & 0.496 & 0.711 & 10 & 5 & 9 \\
\hline Prince Sultan Military College of Health & 0.462 & 0.576 & 0.774 & 11 & 8 & 10 \\
\hline Al-Imam Mohammad Bin Saud Islamic Univ. & 0.540 & 0.552 & 4.140 & 12 & 6 & 13 \\
\hline Institute of Public Administration & 0.556 & 0.632 & 1.390 & 13 & 12 & 11 \\
\hline \multicolumn{7}{|c|}{ New Institutions } \\
\hline Alfaisal University & 0.080 & 0.942 & 0.080 & 1 & 45 & 1 \\
\hline Fakeeh College for Medical Sciences & 0.181 & 0.173 & 0.385 & 2 & 1 & 9 \\
\hline Prince Sultan University & 0.182 & 0.542 & 0.202 & 3 & 25 & 2 \\
\hline Arab Open University & 0.211 & 0.272 & 0.860 & 4 & 4 & 39 \\
\hline IBN Rushd College For Management Science & 0.212 & 0.233 & 0.458 & 5 & 2 & 15 \\
\hline Saad College of Nursing and Allied Healt & 0.215 & 0.543 & 0.215 & 6 & 26 & 3 \\
\hline Al-Baha Private College of Science & 0.249 & 0.254 & 0.648 & 7 & 3 & 32 \\
\hline KSAU-HS & 0.254 & 0.584 & 0.271 & 8 & 31 & 4 \\
\hline Al-Riyada College for Health Sciences & 0.273 & 0.298 & 0.336 & 9 & 5 & 6 \\
\hline KKU & 0.277 & 0.531 & 0.417 & 10 & 24 & 11 \\
\hline Al Baha University & 0.281 & 0.355 & 0.604 & 11 & 7 & 28 \\
\hline Yanbu University College & 0.287 & 0.676 & 0.318 & 12 & 39 & 5 \\
\hline Prince Mohammad Bin Fahd University & 0.296 & 0.721 & 0.350 & 13 & 40 & 7 \\
\hline Taif University & 0.303 & 0.494 & 0.453 & 14 & 18 & 14 \\
\hline University of Business and Technology & 0.310 & 0.472 & 0.484 & 15 & 17 & 16 \\
\hline Taibah University & 0.313 & 0.441 & 0.492 & 16 & 15 & 17 \\
\hline Najran University & 0.316 & 0.404 & 0.430 & 17 & 11 & 12 \\
\hline Shagra University & 0.322 & 0.421 & 0.557 & 18 & 13 & 24 \\
\hline Ha'il University & 0.322 & 0.416 & 0.502 & 19 & 12 & 19 \\
\hline Fahd Bin Sulltan University & 0.325 & 0.362 & 0.615 & 20 & 9 & 31 \\
\hline Arab East Colleges for Postgraduate Stud & 0.342 & 0.346 & 0.411 & 21 & 6 & 10 \\
\hline Sulaiman Alrajhi Colleges & 0.357 & 0.360 & 0.357 & 22 & 8 & 8 \\
\hline Dar Al Uloom University & 0.365 & 0.673 & 0.432 & 23 & 38 & 13 \\
\hline Northern Borders University & 0.370 & 0.447 & 0.797 & 24 & 16 & 37 \\
\hline Al Yamamah University & 0.375 & 0.596 & 0.593 & 25 & 32 & 26 \\
\hline Qassim University & 0.383 & 0.558 & 0.724 & 26 & 30 & 35 \\
\hline Qassim Private Colleges & 0.387 & 0.399 & 0.613 & 27 & 10 & 30 \\
\hline Jazan University & 0.405 & 0.506 & 0.800 & 28 & 21 & 38 \\
\hline Al Jouf University & 0.417 & 0.513 & 0.544 & 29 & 22 & 22 \\
\hline Riyadh College of Dentistry and Pharmacy & 0.433 & 0.638 & 0.689 & 30 & 34 & 33 \\
\hline Effat University & 0.441 & 0.643 & 0.566 & 31 & 35 & 25 \\
\hline University of Dammam & 0.454 & 0.664 & 0.871 & 32 & 36 & 40 \\
\hline Almajmaah University & 0.457 & 0.547 & 1.145 & 33 & 27 & 47 \\
\hline Jubail University College & 0.465 & 0.771 & 0.520 & 34 & 41 & 21 \\
\hline University of Tabuk & 0.467 & 0.425 & 1.902 & 35 & 14 & 49 \\
\hline Prince Sultan College for Business & 0.489 & 0.495 & 0.714 & 36 & 19 & 34 \\
\hline Salman Bin Abdulaziz University & 0.490 & 0.865 & 0.726 & 37 & 42 & 36 \\
\hline Al-Farabi College for Medicine, Dentistr & 0.494 & 0.867 & 0.494 & 38 & 43 & 18 \\
\hline Jubail Technical Institute & 0.496 & 0.496 & 1.000 & 39 & 20 & 45 \\
\hline Dar Al-Hekma University & 0.508 & 0.608 & 0.898 & 40 & 33 & 42 \\
\hline Saudi Electronic University & 0.509 & 1.218 & 0.509 & 41 & 48 & 20 \\
\hline Mohammad Al-mana College for Health Scie & 0.526 & 0.515 & 0.607 & 42 & 23 & 29 \\
\hline Princess Nora bint Abdulrahman Universit & 0.547 & 0.557 & 2.409 & 43 & 29 & 50 \\
\hline Inaya Medical College & 0.549 & 0.549 & 0.549 & 44 & 28 & 23 \\
\hline Yanbu Industrial College & 0.600 & 1.037 & 0.600 & 45 & 46 & 27 \\
\hline Buraydah Collges & 0.628 & 0.667 & 0.889 & 46 & 37 & 41 \\
\hline Batterjee Medical College & 0.827 & 0.882 & 0.990 & 47 & 44 & 44 \\
\hline Al-Ghad International College For Applie & 0.959 & 1.533 & 1.427 & 48 & 50 & 48 \\
\hline Al Maarefa College for Science and Techn & 0.962 & 1.145 & 0.981 & 49 & 47 & 43 \\
\hline Jubail Industrial College & 1.000 & 1.506 & 1.000 & 50 & 49 & 46 \\
\hline
\end{tabular}


Table 7: Separate analysis of teaching and research efficiencies

\begin{tabular}{lcccccccc}
\hline & 2008 & 2009 & 2010 & 2011 & 2012 & 2013 & 2014 & overall \\
\hline Overall & 0.528 & 0.528 & 0.482 & 0.485 & 0.522 & 0.530 & 0.519 & 0.513 \\
Private & 0.495 & 0.495 & 0.436 & 0.480 & 0.528 & 0.541 & 0.518 & 0.499 \\
Public & 0.555 & 0.555 & 0.525 & 0.490 & 0.517 & 0.521 & 0.520 & 0.525 \\
general & 0.476 & 0.476 & 0.491 & 0.508 & 0.531 & 0.533 & 0.539 & 0.509 \\
medical & 0.560 & 0.560 & 0.462 & 0.451 & 0.547 & 0.555 & 0.530 & 0.520 \\
vocational & 0.926 & 0.926 & 0.459 & 0.354 & 0.437 & 0.469 & 0.399 & 0.521 \\
College & 0.569 & 0.569 & 0.455 & 0.430 & 0.499 & 0.514 & 0.455 & 0.491 \\
university & 0.508 & 0.508 & 0.500 & 0.520 & 0.539 & 0.541 & 0.568 & 0.527 \\
New & 0.473 & 0.446 & 0.491 & 0.490 & 0.545 & 0.553 & 0.535 & 0.508 \\
Old & 0.752 & 0.813 & 0.453 & 0.468 & 0.448 & 0.451 & 0.462 & 0.529 \\
& & & Publications production efficiency & & \\
overall & 0.575 & 0.574 & 0.558 & 0.505 & 0.553 & 0.541 & 0.534 & 0.547 \\
private & 0.514 & 0.494 & 0.492 & 0.449 & 0.503 & 0.511 & 0.483 & 0.491 \\
public & 0.627 & 0.645 & 0.620 & 0.565 & 0.600 & 0.567 & 0.582 & 0.598 \\
general & 0.538 & 0.557 & 0.540 & 0.492 & 0.534 & 0.538 & 0.547 & 0.534 \\
medical & 0.475 & 0.488 & 0.514 & 0.455 & 0.495 & 0.483 & 0.443 & 0.477 \\
vocational & 1.237 & 0.932 & 0.813 & 1.074 & 0.819 & 0.682 & 0.661 & 0.833 \\
college & 0.717 & 0.672 & 0.656 & 0.596 & 0.614 & 0.562 & 0.545 & 0.612 \\
university & 0.511 & 0.527 & 0.504 & 0.459 & 0.515 & 0.526 & 0.527 & 0.509 \\
New & 0.577 & 0.559 & 0.584 & 0.514 & 0.559 & 0.562 & 0.557 & 0.558 \\
Old & 0.569 & 0.613 & 0.480 & 0.473 & 0.534 & 0.469 & 0.459 & 0.510 \\
\hline
\end{tabular}


Table 8: Determinants of efficiency estimates

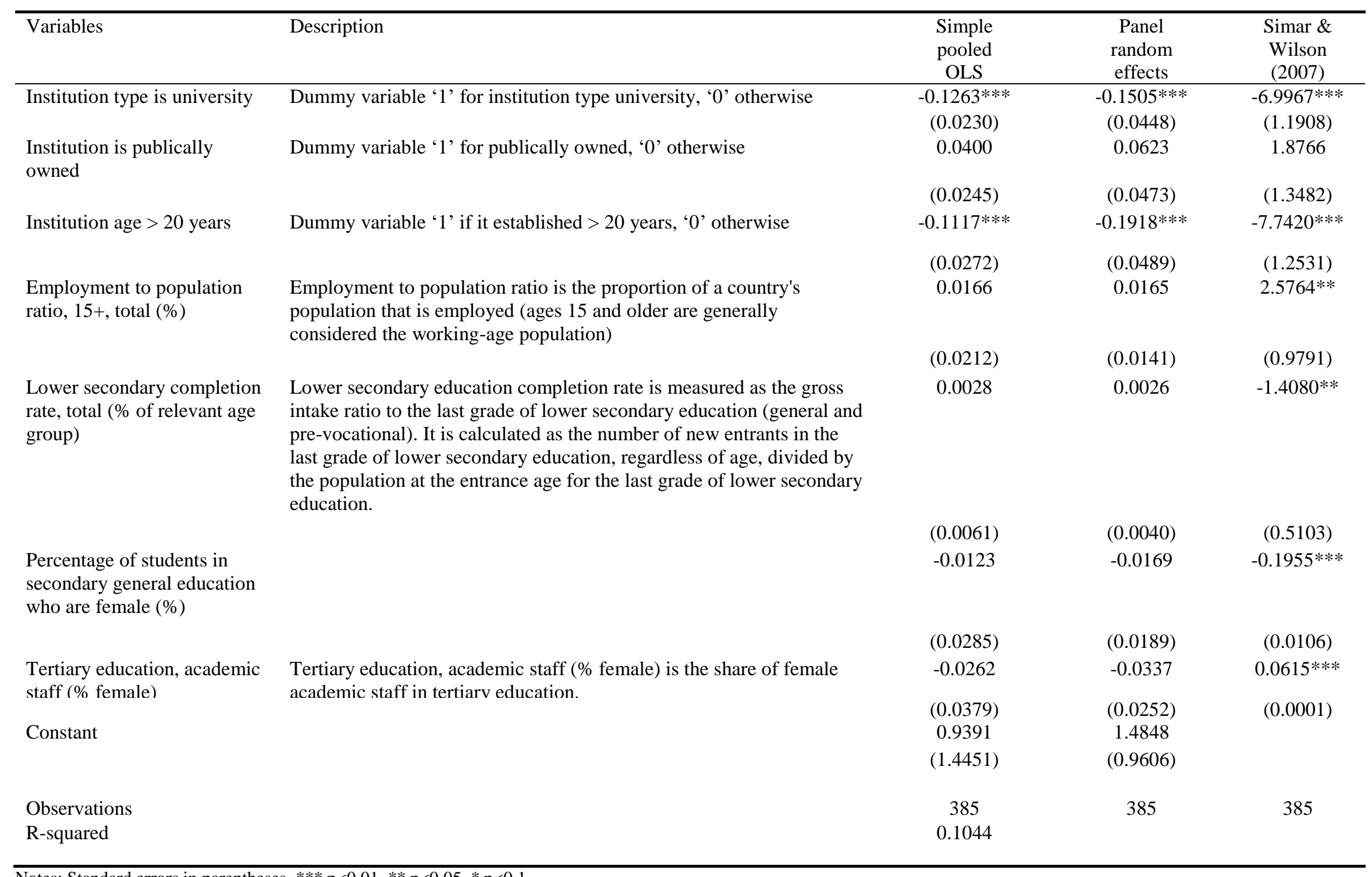

Notes: Standard errors in parentheses. ${ }^{* * *} \mathrm{p}<0.01, * * \mathrm{p}<0.05, * \mathrm{p}<0.1$ 
Figure 1: Kernel Density Estimates

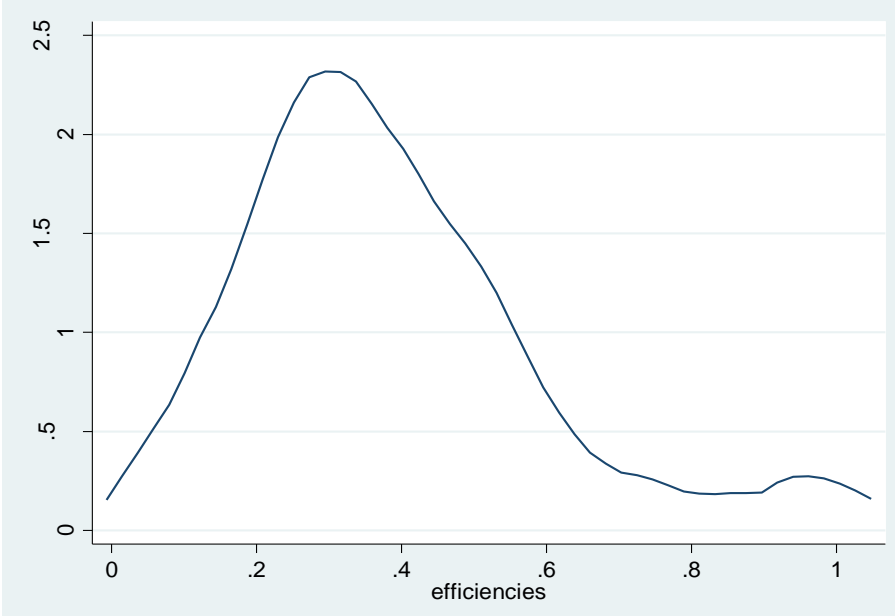




\section{Appendix A: Development of efficiency estimators from traditional to more advanced.}

Continuing with methodological section and following the same conventions, definitions and procedures of Wheelock and Wilson (2008; 2009), Shepherd's (1970) input and output distance functions could be defined as:

$$
\begin{aligned}
& \theta\left(x, y \mid \boldsymbol{p}^{t}\right) \equiv \sup \left\{\theta>0 \mid\left(\theta^{-1} x, y\right) \in \boldsymbol{p}^{t}\right\} \\
& \lambda\left(x, y \mid \boldsymbol{p}^{t}\right) \equiv \inf \left\{\lambda>0 \mid\left(x, \lambda^{-1}\right) \in \boldsymbol{p}^{t}\right\}
\end{aligned}
$$

Input distance function in the above equation (A1) measures the distance from $(x, y)$ to $\boldsymbol{p}^{t \partial}$ in a direction orthogonal to output vector $y$ while the output distance function in the above equation (A2) to input vector $x$. If one assumes constant return to scale (CRS) technology, output distance function is in fact just the reciprocal of input distance function $\theta\left(x, y \mid \boldsymbol{p}^{t}\right)=\left(x, y \mid \boldsymbol{p}^{t}\right)^{-1}$. Due to heterogeneity in the size of the institution (which is present in our case), the variable returns to scale (VRS) however would have serious consequences for efficiency estimates. Färe et al. (1985) tackled the orientation selection issue by measuring distance along a hyperbolic path from a fixed point $(x, y)$ to $\boldsymbol{p}^{t \partial}$ as:

$$
\gamma\left(x, y \mid \boldsymbol{p}^{t}\right) \equiv \sup \left\{\gamma>0 \mid\left(\gamma^{-1} x, \gamma y\right) \in \boldsymbol{p}^{t}\right\}
$$

In this framework, $\gamma(\mathrm{x}, \mathrm{y} \mid \mathrm{P}) \equiv \sup \left\{\gamma>0 \mid\left(\gamma^{-1} \mathrm{x}, \gamma \mathrm{y}\right)\right\} \in$ Pthe true distance function of production set $\boldsymbol{p}^{t}$ is in fact estimated from a set $s n=\left\{x_{\mathrm{i}}, y_{i}\right\}_{i=1}^{n}$ of actual input/output combinations of sampled educational institutions. Subsequently, at the estimation stage, the unknown true $\boldsymbol{p}^{t}$ is represented by an estimator of the production set to attain the estimator of distance function. In this context, Deprins et al. (2006) suggested a free disposal hull (FDH) of the observations in $\mathcal{S}_{n t}^{t}$ as: 


$$
\widetilde{\boldsymbol{p}}\left(\mathcal{S}_{n t}^{t}\right)=\bigcup_{\left(x_{i}, y_{i}\right) \in \mathcal{S}_{n t}^{t}}\left\{(\mathrm{x}, \mathrm{y}) \in \mathbb{R}_{+}^{\mathrm{p}+\mathrm{q}} \mid \mathrm{y} \leq \mathrm{y}_{\mathrm{i}}, \mathrm{x} \geq x_{\mathrm{i}}\right\}
$$

Now for simplicity, by assuming VRS, the widely used DEA estimator could be attained by replacing $\boldsymbol{p}^{t}$ with the convex hull of $\widetilde{\boldsymbol{p}}\left(\boldsymbol{S}_{n t}^{t}\right)$ such as:

$$
\widehat{\boldsymbol{p}}_{D E A}^{t}\left(\delta_{n t}^{t}\right)=\left\{(\mathrm{x}, \mathrm{y}) \in \mathbb{R}_{+}^{\mathrm{p}+\mathrm{q}} \mid \mathrm{y} \leq \sum_{\mathrm{i}=1}^{\mathrm{n}} \kappa_{\mathrm{i}} \mathrm{y}_{\mathrm{i}}, \mathrm{x} \geq \sum_{\mathrm{i}=1}^{\mathrm{n}} \kappa_{\mathrm{i}} \mathrm{x}_{\mathrm{i}}, \sum_{\mathrm{i}=1}^{\mathrm{n}} \kappa_{\mathrm{i}}=1, \kappa_{\mathrm{i}} \geq 0 \forall_{\mathrm{i}}=1, \ldots, \mathrm{n}\right\}
$$

The above measure produces the technical efficiency of a sample institution at a particular time period using input/output combination.

Despite significant progress to establish statistical properties of DEA and FDH estimators, it has been established that both suffer from some serious issues such as slow convergence rates, arbitrary choice of input/output orientation and outlier effect thus requiring many observations to obtain reliable efficiency estimates. DEA based hyperbolic distance function avoids the orientation issue but outlier and dimension issues still remain unresolved. Recently, some authors using the concept of partial frontier have developed a new generation of estimators such as "order-m" and "order- $\alpha$ quantile estimator"1.

\section{Order-m estimators}

Order-m estimators developed by Cazals et al. (2002) is an addition to the family of non-parametric estimators that do not require a convexity assumption. The estimator is root-n consistent and addresses the high input/output dimension issue. Further, due to being constructed on a partial rather than full boundary, it is not affected by outliers. In the spirit of Wheelock and Wilson (2003), a random output oriented distance function utilising a random draw of $m$ output vectors and given inputs could be written as: 


$$
D\left(x, y \mid A_{m}^{t}(x, y)\right) \equiv \inf \left\{\theta>0 \mid(x, y / \theta) \in A_{m}^{t}(x, y)\right\}
$$

For any $\in \mathbb{R}_{+}^{q}$, expected maximum output of order $\mathrm{m}$ is defined in such a way that $f_{x}^{t}(x)=$ $f^{t}(x, y) / f^{t}(y \mid x)>0$ and $y_{m}^{t \partial}(x) \equiv y / \mathrm{E}\left[D\left(x, y \mid A_{m}^{t}(x, y)\right)\right]$

and the order-m proxy of boundary $\boldsymbol{p}^{t}$ is defined as:

$$
\boldsymbol{p}_{m}^{t} \equiv\left\{(x, y) \mid(x, y) \in \boldsymbol{p}^{t}, y \leq y_{m}^{t \partial}(x)\right\}
$$

The closure of the complement of $\boldsymbol{p}_{m}^{t}$ is labelled as order-m frontier and is expressed as $\boldsymbol{p}_{m}^{t \partial}$. Under this unique approach, observed output quantity of an institution is compared to what could be expected from any $\mathrm{m}$ randomly chosen institution that does not use more input quantities than the institution in question. A Monte Carlo method developed by Cazals et al. (2002) could be utilised to estimate maximum feasible output of chosen $m$ random institution and then performance could be compared against this benchmark. Similarly, the order-m input frontier at input level $x_{0}$ is estimated as:

$$
\boldsymbol{p}_{m}^{\partial}\left(x_{0}\right) \equiv \mathrm{E}\left[\max \left(y_{1}, \ldots, y_{m}\right) \mid x \leq x_{0}\right]
$$

When it comes to the selection of the value of trimming parameter $\mathrm{m}$, empirical studies utilising this estimator have suggested different values ranging from five to hundred or more. We also experimented with lower and higher values of $\mathrm{m}$ but results did not significantly differ qualitatively. In this study, we chose $m=5$ in our subsequent estimation of order-m efficiency estimates in both directions (output/ input orientation). 
Notes

${ }^{1}$ See Cazal et al. (2002) for "order-m" estimator and Aragan et al. (2005) and Daouia and Simar (2007) for conditional/unconditional "order- $\alpha$ " quantile. 